\title{
Insights Into the Source of Magmatic Hot-Lines: Forty Years of Geophysical Studies of the Cameroon Volcanic Line
}

\author{
Aubreya Adams * \\ Colgate University, Department of Geology, Hamilton, NY, United States
}

The Cameroon Volcanic Line (CVL) of west Africa poses many challenges to common models of mantle processes and volcanic system genesis. Although the CVL superficially resembles the hot-spot trace of a mantle plume, there is no evidence for age progression of initiation or cessation of volcanic activity, making the CVL one of several hot-lines observed on Earth, which exhibit asynchronous volcanism along each line. This unusual form of volcanic system, together with the complexity of the surrounding geology, which includes a Mesozoic rift, an Archean Craton, a Proterozoic mobile belt, and a major continental-scale shear zone, have fueled numerous geophysical investigations of the crust and upper mantle structure within the region. This review highlights major findings from geophysical

OPEN ACCESS

Edited by: Mohamed Sobh,

Freiberg University of Mining and Technology, Germany

Reviewed by: Mohamed Abdelsalam, Oklahoma State University, United States Emmanuel Njinju, Virginia Tech, United States

*Correspondence: Aubreya Adams aadams@colgate.edu

Specialty section: This article was submitted to Solid Earth Geophysics, a section of the journal Frontiers in Earth Science

Received: 19 December 2021 Accepted: 24 January 2022 Published: 22 February 2022

Citation: Adams A (2022) Insights Into the Source of Magmatic Hot-Lines: Forty Years of Geophysical Studies of the

Cameroon Volcanic Line.

Front. Earth Sci. 10:838993.

doi: 10.3389/feart.2022.838993 studies, including controlled source and passive source seismic studies and gravimetric modeling, conducted in the late 20th and early 21st centuries. Potential geodynamic models for the formation of the CVL are examined and evaluated based on the body of geophysical evidence. Finally, several key outstanding questions about the structure and formation of the CVL are highlighted, potentially guiding future studies of this region.

Keywords: mantle convection, mantle plume, africa, volcanic line, tectonics, volcanism, lithosphere

\section{INTRODUCTION}

The Cameroon Volcanic Line (CVL) in west Africa is a geologic enigma that challenges many current models for mantle dynamics, tectonics, and volcanism. The CVL consists of an $1800 \mathrm{~km}$ long linear chain of active volcanoes and plutonic structures. It is comprised of two sections of roughly equal lengths-an onshore section within the Adamawa Plateau of Cameroon, and an offshore section of volcanic islands including Annobòn (Pagalú) and Bioko as well as the island nation of São Tomé and Príncipe (Figure 1). Volcanism along the CVL dates from $66 \mathrm{Ma}$ to the present, without any systematic change in the onset of volcanism or in the age of the most recent volcanic activity (Figure 2; e.g., Hedberg, 1969; Deruelle et al., 1991; Deruelle et al., 2007; Marzoli et al., 1999; Marzoli et al., 2000; Ngounouno et al., 2005; Ngounouno et al., 2006; Kamgang et al., 2010; Asaah et al., 2015).

The linear nature of the CVL has led many studies to describe it as a classic Wilson-Morgan hot spot trail created by a mantle plume, in which a linear chain of age-progressive volcanoes are produced (e.g., Morgan, 1972; Morgan, 1983; Van Houten, 1983; Duncan and Richards, 1991; O'Connor and Le Roex, 1992; Lee et al., 1994; Burke, 2001). The CVL, however, displays several firstorder characteristics that fundamentally differ from those that define a hot spot trail, leading other studies to conclude that the CVL is inherently inconsistent with its formation by a mantle plume (e.g., Poudjom Djomani et al., 1995; Reusch et al., 2010; Adams et al., 2015).

The characteristics of a mantle plume are debated in scientific literature. The traditional WilsonMorgan model of a mantle plume includes a narrow thermal anomaly seated in the deep mantle, 


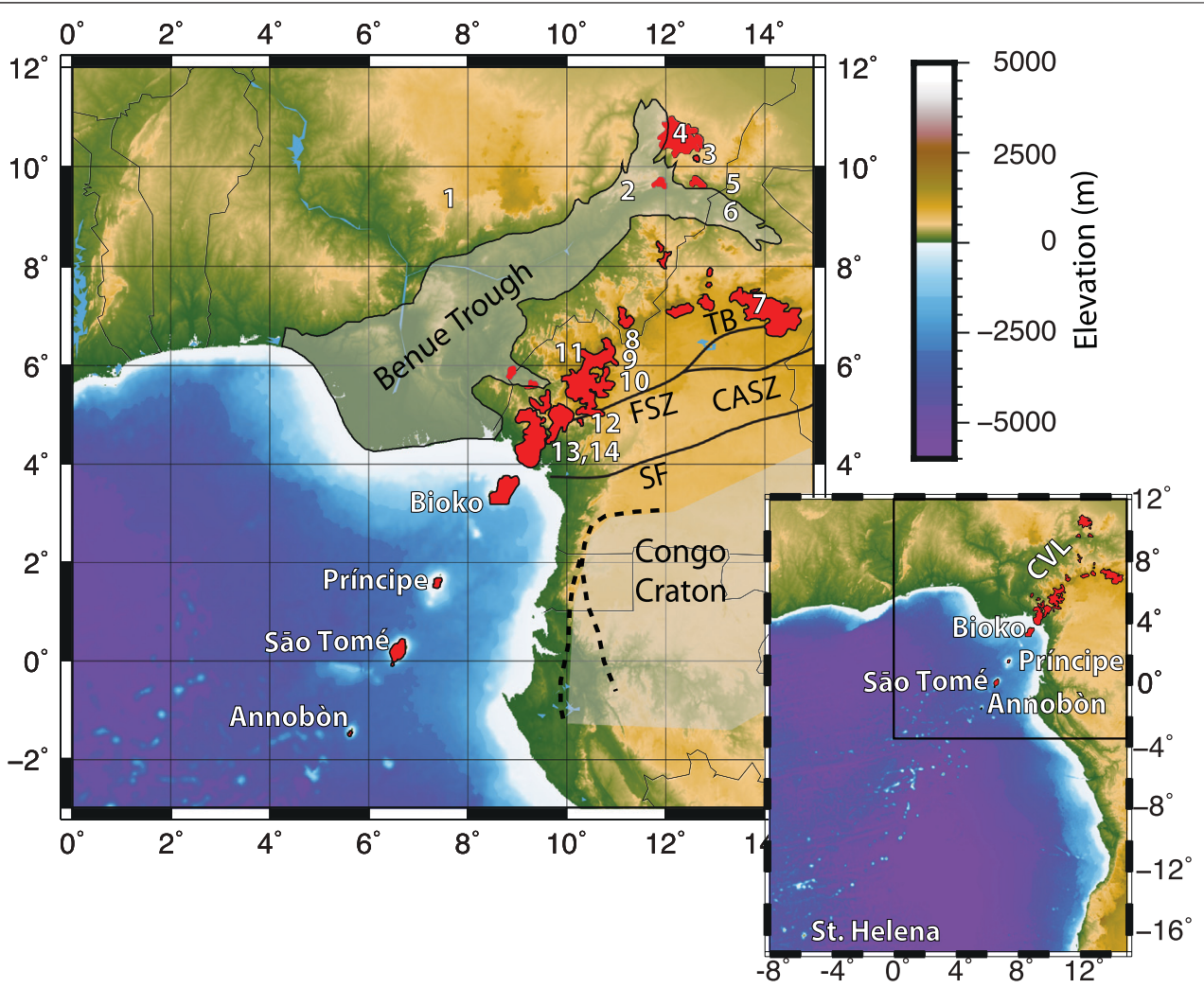

FIGURE 1 | Geologic map of the CVL and surrounding regions. Volcanic provinces of the CVL are shown in red, and the Congo Craton and the Benue Trough are shade in gray. Bold lines represent the CASZ, including the Foumbian Shear Zone (FSZ), Tcholliré-Banyo Shear Zone (TB), and the Sanaga Fault (SZ). White numbers and labels indicate the locations of volcanic centers dated in Figure 2. The inset shows the CVL in relation to St. Helena and nearby seamounts. The area of the primary map is shown with a black rectangle.

\begin{tabular}{|c|c|c|c|c|c|c|}
\hline & Locations & $0-10 \mathrm{Ma}$ & $11-20 \mathrm{Ma}$ & $21-30 \mathrm{Ma}$ & $31-40 \mathrm{Ma}$ & 41-42 Ma \\
\hline 1 & Jos Plateau & & & & & \\
\hline$\frac{2}{2}$ & Benue Trough & & & & & \\
\hline 3 & Mandara Mtns/ Kapsiki Plateau & & & & & \\
\hline 4 & Biu Plateau & & & & & \\
\hline 5 & Mayo Oulo-Lere/Babouri-Fiquil & & & & & \\
\hline 6 & Garoua Valley & & & & & \\
\hline 7 & Nagandere & & & & & \\
\hline 8 & Oku & & & & & \\
\hline 9 & Sabga & & & & & \\
\hline 10 & Fongo Tongo \& Bandjoum & & & & & \\
\hline 11 & Bambouto & & & & & \\
\hline 12 & Manenguoba & & & & & \\
\hline 13 & Mt Cameroon & & & & & \\
\hline 14 & Etinde & & & & & \\
\hline & Bioko & & & & & \\
\hline & Principe & & & & & \\
\hline & Sao Tome & & & & & \\
\hline & Annobon & & & & & \\
\hline
\end{tabular}

FIGURE 2 | Ages of volcanic activity at volcanic centers along the continental CVL (\#1-14) and the oceanic portions (by island name) of the CVL. Volcanic center locations are shown in Figure 1 (Hedberg, 1969; Grant et al., 1972; Grunau et al., 1975; Dunlap and Fitton, 1979; Cornen and Maury, 1980; Dunlap, 1983; Fitton and Dunlap, 1985; Lee et al., 1994; Ngounouno et al., 1997; Marzoli et al., 1999; 2000; Ngounouno et al., 2001; 2003; Njilah et al., 2004; Ngounouno et al., 2005; 2006), illustrating the lack of age progression for initiation or cessation of volcanism along the CVL. Reproduced with permission from Reusch et al. (2010).

which is stationary within the mantle over time (Wilson, 1963; Morgan, 1971; Morgan, 1972). Such a plume should 1) produce a linear chain of volcanos that parallels plate motion, 2) extend from an older large igneous province produced by the initial plume head, 3) show a progression in age of onset and cessation of volcanic activity along the line, and 4) produce basalts with geochemical signatures distinct from mid-ocean ridge basalts (e.g., Wilson, 1963; Morgan, 1971; Campbell, 2007; and 
sources therein). More recent adaptations to the plume hypothesis include plumes that are not stationary within the mantle (e.g., Molnar and Stock, 1987; Steinberger et al., 2004), plumes that originate from shallower depths of the mantle (e.g., Burke and Torsvik, 2004), plumes that lack an initial plume head forming a large igneous province (e.g., Farnetani and Samuel, 2005; Davies and Bunge, 2006), or plumes with significant geochemical overlap with mid-ocean ridge basalts (Chadwick et al., 2005; White, 2010). All theories for the existence of mantle plumes, however, concur that a plume should produce a line of volcanos with age progression and an orientation parallel to plate motion. The CVL notably does not meet these "minimum requirements", displaying no age progression and having an orientation that is sub-perpendicular to plate motion in a hotspot frame of reference (Gripp and Gordon, 1990). Furthermore, geochemical evidence to support or refute the presence of a mantle plume associated with the CVL is equivocal.

Numerous geophysical and geochemical studies have been conducted across the CVL since 1980 to delineate the characteristics of this volcanic line and to gain insight into the processes that formed and continue to drive it. Geochemical studies of the CVL were reviewed and analyzed by Asaah et al. (2015). In this study, I present a review of insights from geophysical studies from the last 40 years, and analyze the potential geodynamic models that may have formed the enigmatic CVL.

\section{GEOLOGIC SETTING}

\section{The Cameroon Volcanic Line}

The CVL consists of multiple volcanic and plutonic bodies arrayed a narrow line that roughly bifurcates the bend of central western Africa at the Gulf of Guinea. The onshore CVL lays atop the Adamawa Plateau, a broad topographic region with approximately $1 \mathrm{~km}$ of uplift and consists of seven major volcanic centers including Mt. Cameroon as well as Mts. Bambouto, Entinde, Mandara, Manengouba, and Oku (Tabod et al., 1992). The offshore CVL lays atop an asymmetrical $200 \mathrm{~km}$ wide crustal arch with up to $3 \mathrm{~km}$ of uplift, with major volcanic centers marked by the islands of Annobòn, São Tomé, Príncipe, and Bioko (Meyers and Rosendahl, 1991; Meyers et al., 1998). Igneous materials consist primarily of alkaline plutonic rings and alkaline basalts (Hedberg, 1969;Deruelle et al., 1991; Deruelle et al., 2007). Continental Precambrian crystalline basement rocks are part of the Oubanguides Belt, a zone of Neoproterozoic metamorphosed mobile belts dating to the Neoproterozoic Pan-African orogeny, and forming part of the Central African Orogenic Belt (e.g., Nzenti et al., 1988; Castaing et al., 1994; Marzoli et al., 2000).

The CVL strikes at approximately $\mathrm{N} 30^{\circ} \mathrm{E}$, with little apparent change in orientation within the continental and oceanic sections. Both distal ends of the CVL show divergence from the central line. In the northeast, the northern CVL splits into two distinct lines extending $300 \mathrm{~km}$ north and $200 \mathrm{~km}$ east, creating a Y-shaped terminus. Southwest of Annobòn, the CVL connects to a broad field of numerous seamounts, $700 \mathrm{~km}$ across, extending to St. Helena. It is notable that the long axis of this broad Annobòn-Helena seamount field roughly follows the overall orientation of the CVL (see inset of Figure 1). The apparent connection between the CVL, the Annobòn-Helena seamount field, and the island of St. Helena have led some authors to suggest that the CVL may be part of a broader mantle feature (e.g., Morgan, 1972; Morgan, 1983; Duncan and Richards, 1991; Meyers et al., 1998).

\section{Surrounding Regions}

North of the CVL and along the northern border of the Adamawa Plateau lies the Benue Trough, a linear sediment-filled dormant rift formed during the rifting of the Atlantic Ocean, 140-84 Ma (e.g., Burke et al., 1970; Fitton, 1980; Maluski et al., 1995). The Benue Trough is oriented sub-parallel to the CVL, and splits into two smaller rifts near the northeastern termination, forming a Y-shaped intersection and mirroring the shape of the northern CVL. The eastern most portions of the Benue Trough overlap with the northern most extension of the CVL in the Garoua Rift region. The Benue Trough was also volcanically active during and after rifting, with andesitic and basaltic deposits dating to 147-106 Ma in the north and 97-9 Ma in the south (e.g., Carter et al., 1963; Burke et al., 1970; Uzuakpunwa, 1974; Olade, 1978; Maluski et al., 1995). These morphologic and volcanic similarities between the Benue Trough and the CVL have led many authors to infer some dynamic relationship between the two features (e.g., Fitton 1980; Fitton et al., 1983; Fitton, 1987). For example, Fitton et al. (1983) suggested that a thermal anomaly in the upper mantle may have migrated from the Benue Trough to the CVL due to changes in mantle convection or plate motion. More recent geophysical studies, however, identify key differences between the crustal and upper mantle structures in these regions, suggesting that the two features may not share a common cause. The relationship between the two features, or even if any causal relationship exists, remains unanswered.

The CVL is roughly aligned with the Central African Shear Zone (CASZ), which locally includes the Foumbian Shear Zone, Tcholliré-Banyo Shear Zone, and the Sanaga Fault (SZ) as the Foumbian Shear Zone (Dorbath et al., 1986; Toteu et al., 2004; Nzenti et al., 2006). The CASZ in Cameroon consists of several mylonitic shear zones within the Oubanguides Belt and shows a complex series of both dextral and sinistral shear that began with the collision of multiple cratons during the formation of Gondwana (Toteu et al., 2004). This major intercontinental structure runs from northeastern Africa, through the central African continent, and along southern boundary of the CVL (Fairhead and Okereke 1987). Prior to the opening of the Atlantic Ocean during the Mesozoic, the CASZ continued into what is now the Pernambuco lineament of South America. Within the Atlantic Ocean, the previously existing CASZ may have influenced the large transform offsets observed for the Ascension Fracture Zone at the mid-Atlantic Ridge (Burke et al., 1971; Browne and Fairhead 1983).

The CASZ separates the CVL from the Congo Craton, the largest of several pre-Cambrian blocks that form the framework of the African continent. Archean to Paleoproterozoic in age, the Congo Craton occupies a substantial portion of sub-Saharan Africa, but is buried by major sedimentary basins in many locations. The Congo Craton is exposed in southern 
Cameroon as the Ntem Complex, which forms the northwestern boundary of the craton (Vicat et al., 1996). The northern boundary is overthrust by the Oubanguides Belt, while the western boundary is obscured by coastal sediments, making the delineation of the Congo Craton's boundary relative to the CVL challenging in these locations (Boukeke, 1994).

\section{Dating and Mantle "Hot Lines"}

Igneous activity associated with the CVL began in the Paleocene, with the intrusion of alkaline plutonic ring complexes 66-30 Ma (Deruelle et al., 1991; Deruelle et al., 2007). Volcanic activity began $42 \mathrm{Ma}$ within the continental portion of the CVL, while offshore volcanism began $30 \mathrm{Ma}$ (Figure 2; e.g., Grunau et al., 1975). The initiation of offshore volcanism correlated with the formation of the offshore crustal arch, but uplift of the Adamawa Plateau began in the Miocene, after the onset of both plutonic and volcanic activity (Hedberg, 1969; Browne and Fairhead, 1983; Fitton et al., 1983; Fitton, 1987; Okereke, 1988; Meyers and Rosendahl, 1991; Meyers et al., 1998).

Volcanism continues to the present across both the oceanic and the continental CVL. No clear age progression along the line is observed either for age of onset or for the most recent volcanic activity, nor is any consistent pattern seen in the duration of active volcanism (Figure 2; e.g., Hedberg, 1969; Grant et al., 1972; Grunau et al., 1975; Dunlap and Fitton, 1979; Cornen and Maury, 1980; Dunlap, 1983; Fitton and Dunlap, 1985; Lee et al., 1994; Ngounouno et al., 1997; Marzoli et al., 1999, Marzoli et al., 2000; Ngounouno et al., 2001, Ngounouno et al., 2003; Njilah et al., 2004; Ngounouno et al., 2005, Ngounouno et al., 2006; Aka et al., 2009; Kagou Dongmo et al., 2010; Kamgang et al., 2010). Some studies of basalts from the oceanic sector suggest a possible progression in age of onset-but not in age of cessation-from the islands of Annobòn to Príncipe, but this apparent trend may reflect bias due to the very limited sampling from these islands (Grunau et al., 1975; Meyers and Rosendahl, 1991; Meyers et al., 1998).

This lack of age progression along the CVL has long been recognized as a challenge to the interpretation of the volcanic chain as a hot spot trace from a mantle plume, leading some studies to dub this and other linear volcanic chains without age progression as "hot lines" in the mantle (e.g., Bonatti and Harrison, 1976; Meyers et al., 1998). Numerous alternative causal mechanisms have been proposed for the formation of the CVL. Some models for formation are adaptations of the plume hypothesis, including the superposition of multiple mantle plumes with overprinting ages (Ngako et al., 2006; Njome and Wit, 2014) or the diversion of plume material from east Africa along the CASZ, reaching the surface at the CVL (Ebinger and Sleep, 1998). Other studies suggest that the CVL formation was influenced by the Benue Trough (e.g., Fitton 1980; Fitton et al., 1983; Stuart et al., 1985; Fitton, 1987) or by active rifting (e.g., Okereke, 1988). A number of studies attribute the formation of the CVL to local or regional patterns in mantle convection. Two studies suggest that local edge convection may be induced along the northern boundary of the Congo Craton. This edge convection would flow laterally from the Craton to the CVL at shallow sub-lithospheric depths if the asthenosphere beneath the Craton is heated due to insulation (King and Anderson, 1995) or would form a downwelling beneath the edge of the Craton and an

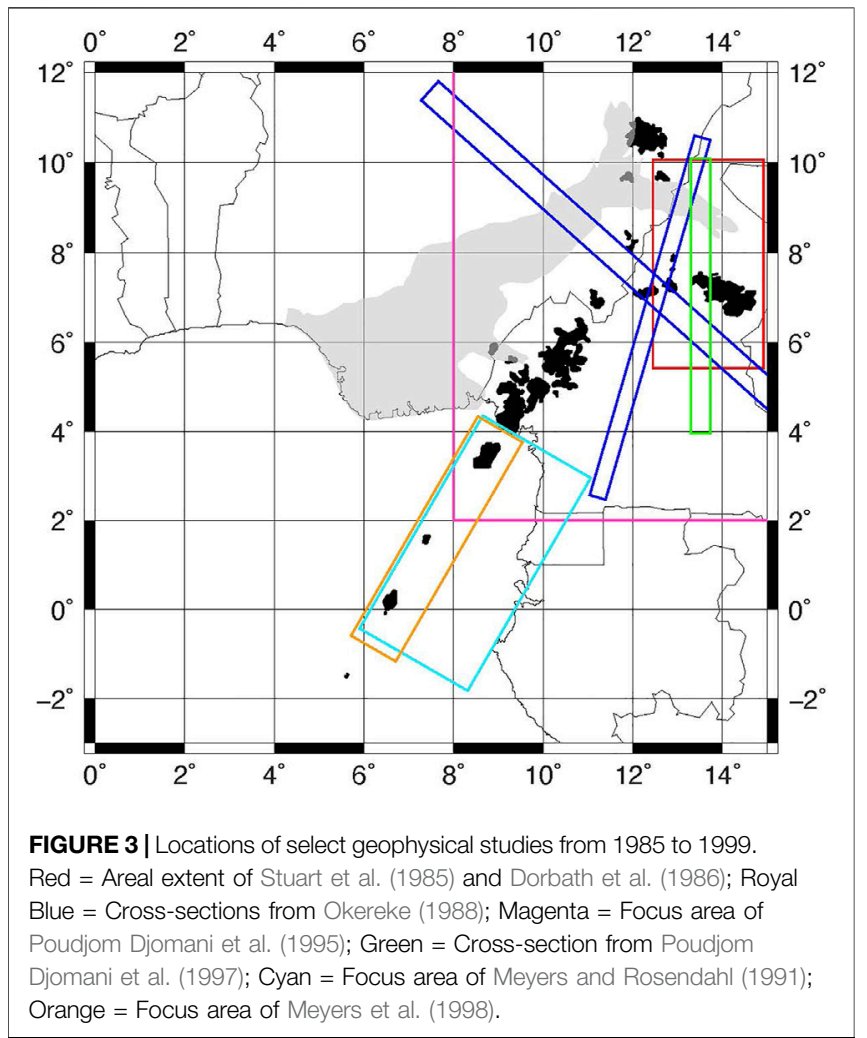

upwelling beneath the CVL if the asthenosphere beneath the Craton is not anomalously warm (King and Anderson, 1998; King and Ritsema, 2000). Analog models by Milleli et al. (2012) indicate that edge convection may also be induced perpendicular to a continental margin due to the contrast in lithospheric thickness between continental and oceanic lithosphere. Meyers et al. (1998) alternatively suggest that the CVL may result from a convective roll induced by shear along the base of the mantle transition zone.

Volcanic lines lacking age progression also exist in other regions, most notably in the south Pacific. The Austral-Cook line of volcanos in the south Pacific, for example, lacks the clear age progression typical of a mantle plume. It has instead been suggested that this line of volcanos is formed by three superimposed mantle plumes rooted in the South Pacific Superplume (Bonneville et al., 2006). To the north, the central Pacific Line Islands also lack a clear age progression, which has been attributed to interactions with a spreading ridge or transform fault or to thermal feedback (Epp, 1984). Still other studies in this region attribute these "hot-lines" to a combination of shallow, short-lived plumes and lithospheric extension (Koppers et al., 2003).

\section{TH CENTURY GEOPHYSICAL STUDIES (1985-1999)}

Early geophysical studies of the CVL and surrounding regions during the 1980s focused primarily on the crustal and lithospheric structures. These studies used a combination of 
gravity (Fairhead and Okereke, 1987; Okereke, 1988), controlled source seismic refraction (Stuart et al., 1985), and teleseismic delay times (Dorbath et al., 1986) to image structures beneath the land portion of the CVL on the Adamawa Plateau and surrounding regions. Most of these studies focused on the northernmost portions of these features, where the Benue Trough, the CVL, and the CASZ overlap. In the 1990s, additional data were gathered and analyzed on land (Poudjom Djomani et al., 1995; Poudjom Djomani et al., 1997), and the study of the CVL expanded to include imaging of the oceanic sector using seismic reflection and gravity data (Meyers and Rosendahl, 1991; Meyers et al., 1998). By the end of the 1990s, a number of first-order characteristics of the CVL lithosphere were determined. Figure 3 shows the areas of focus for selected 20th century geophysical studies described below.

\section{Studies of the Land Sector}

One of the earliest geophysical studies of crustal structure of this region used seismic refraction of 5 months of quarry blasts recorded on 40 vertical seismometers to image the crustal structure for a $200 \mathrm{~km}$ long transect across the northernmost Benue Trough into the Adamawa Plateau (Stuart et al., 1985). One dimensional velocity models were developed for both the Benue Trough and the Adamawa Plateau. Similar crustal velocities were found in both regions, but a notable change was observed in crustal thickness and upper-most mantle velocities. Crustal thickness changed from $23 \mathrm{~km}$ beneath the rifted Benue Trough to $33 \mathrm{~km}$ beneath the Adamawa Plateau and the northernmost CVL. This change was primarily due to a thinned lower crust beneath the Benue Trough. Upper mantle $\mathrm{P}$-wave velocities beneath the Benue Trough are reduced to $7.8 \mathrm{~km} / \mathrm{s}$ compared to $8.0 \mathrm{~km} / \mathrm{s}$ beneath the Adamawa Plateau, suggesting that rifting has affected the lower crust and upper lithospheric mantle in the Benue Trough in the north, but that the formation of the CVL has not thinned the crust nor altered the upper lithospheric mantle. This is corroborated by the presence of a positive Bouguer gravity anomaly beneath the rift, and the lack of a similar corresponding anomaly beneath the CVL (Collignon, 1968; Stuart et al., 1985). The nature of the transition from the thinned Benue Trough to the thicker crust of the Adamawa Plateau is not clearly imaged but must occur over a narrow zone. This sharp transition likely predated the formation of the CVL and may have provided a pre-existing zone of weakness along which subsequent volcanic activity was concentrated, possibly leading to the similarity in the shape of the Benue Trough and the CVL (Stuart et al., 1985).

Dorbath et al. (1986) used teleseismic P-wave delay times recorded on the same seismic deployment used by Stuart et al. (1985) to build the earliest 3D P-wave velocity model of the CVL. This study focused on lithospheric-scale velocity structure to a depth of $190 \mathrm{~km}$ in the Garoua Rift region at the northern end of the Benue Trough and Adamawa Plateau. A region of low velocities was found directly beneath the location where the CASZ crosses the northernmost CVL near the Garoua Rift. This low velocity region is bounded to the north and south by lithospheric blocks with higher velocities. The contrast between velocities in these regions extends to all depths within the model and increases with depth; however, the greatest velocity contrast at any depth is $2.5 \%$, which is considerably lower than velocity contrasts in other volcanically active regions (Dorbath et al., 1986). The authors suggest based on this shallow regional model that a large upper mantle velocity anomaly might lie beneath the entire Adamawa Plateau, but that previously existing zones of weakness associated with the CASZ allow heat and magma to reach the surface at the intersection of the CASZ and the CVL (Dorbath et al., 1986).

A regional survey of Bouguer gravity anomalies was conducted across west-central Africa by Fairhead and Okereke (1987), and two cross-sections from the gravity model through the northern CVL were interpreted and modeled by Okereke (1988). The data showed a long-wavelength positive Bouguer anomaly beneath the Benue Trough, paralleled by a long-wavelength negative anomaly beneath the Adamawa Plateau (Fairhead and Okereke, 1987). Forward models of the data suggested the positive anomaly beneath the Benue Trough represents thinned crust formed through extension, with low density lower crust replaced by high density lithospheric mantle. The negative anomaly beneath the Adamawa Plateau, however, is best modeled with thinned lithosphere but minimal crustal thinning (Okereke, 1988). Okereke (1988) notes the similarity between the broad negative Bouguer anomaly beneath the Adamawa Plateau and a similar anomaly beneath the East African Plateau associated with the East African Rift System. This pattern of anomalies is interpreted to reflect passive-style rifting in the Benue Trough due to tensional forces in the crust, and to reflect active-style rifting in the CVL due to upwelling of the asthenospheric mantle (Okereke, 1988).

Regional gravity anomalies were reexamined in the 1990s using data from higher resolution surveys. Poudjom Djomani et al. (1995) built new gravity and topography datasets combined from multiple sources, including data from approximately 32,000 locations. Combining both datasets, they determined effective elastic thickness $\left(\mathrm{T}_{\mathrm{e}}\right)$ and crustal thickness $\left(\mathrm{T}_{\mathrm{c}}\right)$ across the Benue Trough, Adamawa Plateau, the CVL, and the northernmost Congo Craton. They found a first-order pattern of decreasing crustal thickness from south to north, with $\mathrm{T}_{\mathrm{c}}$ reaching a maximum of $50 \mathrm{~km}$ beneath the Congo Craton to the south and reaching a minimum of $14 \mathrm{~km}$ north of the Benue Trough. Poudjom Djomani et al. (1995) found a secondary pattern similar to the regional patterns observed by earlier studies, with thinner crust beneath the Benue Trough relative to the Adamawa Plateau, but considerable variation was found within each region. Within the Benue Trough, the CVL, and the Adamawa Plateau $T_{e}$ was low. Within the Benue Trough, a spatial change was observed, with $T_{e}$ transitioning from $16 \mathrm{~km}$ in the south to $23 \mathrm{~km}$ in the north. $\mathrm{T}_{\mathrm{e}}$ for the CVL was estimated to be $18+2 /-4 \mathrm{~km}$, and a similar value of 14-16 km was estimated for the remainder of the Adamawa Plateau. Notably, $T_{e}$ values in these regions are lower than values typically found in rifted or volcanically active areas in Africa (26-35 km; Betchtel et al., 1987; Ebinger et al., 1989), suggesting the presence of an unusually weak lithosphere in these regions. The CVL and the Benue Trough, however, are separated by an area with high $T_{e}$, up to $34+4 /-8 \mathrm{~km}$, suggesting that a block of strong lithosphere separates the two features. The Congo 
Craton is marked by high values of $\mathrm{T}_{\mathrm{e}}$, varying between 30 and $40 \mathrm{~km}$, and reflecting the existence of strong, cratonic lithosphere. Poudjom Djomani et al. (1995) conclude that there is a consistent relationship between low values of $\mathrm{T}_{e}$ and regions of volcanic activity and rifting. They suggest that low values of $\mathrm{T}_{e}$ for the CVL are probably due to volcanism and thermal alteration, while low $\mathrm{T}_{\mathrm{e}}$ values for the Benue Trough are likely due to weakening of the lower crust through extension and shearing (Poudjom Djomani et al., 1995).

Poudjom Djomani et al. (1997) built an updated 2D model of lithospheric densities along a north-south profile through the eastern portion of the CVL using the combined gravity model of Poudjom Djomani et al. (1995). This profile shows the same longwavelength positive and negative Bouguer anomalies beneath the Benue Trough and the Adamawa Plateau, respectively, that were observed by Okereke (1988), but also resolves a small $80 \mathrm{~km}$ wide positive anomaly superimposed on the Adamawa negative anomaly. The broad positive anomaly beneath the Benue Trough results from a gradual thinning of the crust from $33 \mathrm{~km}$ at its edge to $22 \mathrm{~km}$ at its center. The superposition of the narrow positive anomaly on the broad negative anomaly of the Adamawa Plateau is interpreted as a thinned $23 \mathrm{~km}$ thick crust beneath the CASZ, underlain by a thinned lithosphere ranging from 120 to $80 \mathrm{~km}$ thick. This is a notable difference from the prior studies of crustal structure from Bouguer gravity anomalies and seismic refraction, which found no evidence of crustal thinning beneath the Adamawa Plateau (Stuart et al., 1985; Okereke, 1988). The authors note that while their models show similar degrees of crustal thinning beneath the CVL and the Benue Trough, other characteristics of these regions are distinct. The Benue Trough is characterized by a positive Bouguer anomaly, low topography, and no lithospheric thinning, while the Adamawa Plateau is characterized by a small positive anomaly within a broader negative Bouguer anomaly, high topography, and a thinned lithosphere. These findings support a conclusion similar to that of Poudjom Djomani et al. (1995), that the Benue Trough formed through passive extensional rifting from far-field forces, while the CVL formed through active upwelling from the mantle, which has been influenced by the weakened crust of the CASZ (Poudjom Djomani et al., 1997).

\section{Studies of the Oceanic Sector}

During the 1990s, several key studies were conducted to characterize the deep crustal and lithospheric structure of the offshore portions of the CVL. Earlier seismic reflection studies conducted in the Gulf of Guinea focused on sedimentary layers, with limited resolution of crystalline basement rocks (e.g., Pautot et al., 1973; Emery et al., 1975; Grunau et al., 1975; Lehner and de Ruiter, 1977). Meyers and Rosendahl (1991) used long-offset seismic reflection to image both sedimentary layers and deep crustal structure between the oceanic sector of the CVL and the Gulf of Guinea, revealing that the CVL sits on arched oceanic crust, with an estimated maximum uplift of $3 \mathrm{~km}$. The crustal arch is asymmetrical with a steeper limb on the southern side and may represent an extension of the uplift associated with the Adamawa Plateau (Meyers and Rosendahl, 1991). Regional stratigraphy showed that uplift began during the Miocene and was synchronous along-strike. This apparent lack of age progression in uplift, together with lack of age progression in volcanism suggests that the oceanic CVL was not formed by a traditional mantle plume. Meyers and Rosendahl (1991) note the spatial correlation between the oceanic arch and the CASZ and suggest that the previously existing structures formed by the CASZ may have influenced the surficial expression of a broad asthenospheric upwelling. These pre-existing structures may have led to the asymmetry of the arch and permitted the flow of magma through fracture zones, forming the regularly spaced volcanos that comprise the oceanic CVL (Meyers and Rosendahl, 1991).

A later study used a combination of gravity and 2D seismic reflection surveys along-strike and sub-perpendicular to the oceanic crustal arch of the CVL and lent further insights into the structure and geologic history of the oceanic CVL (Meyers et al., 1998). Although Moho reflections directly beneath the axis were not imaged, Moho reflections shallowed towards the axis of the arch, suggesting that the crust likely maintains a constant thickness across the arch. Normal faulting of the Precambrian crystalline basement and sedimentary layers were observed near the axis of the arch, but the uplift of the arch was primarily accommodated by bending of the lithosphere, rather than by large amounts of slip on these faults or accumulation on surface materials (Meyers et al., 1998). The study finds distinct differences between the crustal structure of the CVL and that of traditional mantle plume traces in the ocean. Most notably, the CVL crustal arch is built primarily of sediments, with less than $2 \mathrm{~km}$ of mixed igneous and syn-volcanic sedimentary layers capping $4-5 \mathrm{~km}$ of sediments (Meyers et al., 1998). This pattern is in stark contrast to the crustal structure of the Hawaiian hot spot, which consists primarily of thick deposits of volcanic material on top of oceanic crust and sediments of typical thickness, forming large shield volcanos (e.g., Watts et al., 1985). The authors note similarities in orientation for other volcanic island chains in the southeast Atlantic, which also show evidence of crustal uplift and limited evidence for age progression. These observations lead to one hypothesized mechanism for the formation of the CVL, shear induced convective rolls, which is described in detail in Section 5 (Meyers et al., 1998).

\section{Seismicity}

The CVL and surrounding regions show limited levels of seismicity compared with other tectonically or volcanically active regions, but small earthquakes have long been felt and reported during eruptive episodes (Fairhead, 1985; Ambraseys and Adams, 1986), and a limited number of regional stations were used to record seismic activity around the CVL by the 1960 s (Tabod et al., 1992). To better characterize seismicity in the region, the first seismometer was installed in Cameroon in 1982 and detected increased seismic activity during an eruption at Mt. Cameroon later that year (Fairhead, 1985). Following the fatal emission of concentrated $\mathrm{CO}_{2}$ in 1984 due to the overturning of the deep volcanic lake, Lake Monoun, additional seismic monitoring stations were installed in Cameroon and were operating during a second fatal emission 


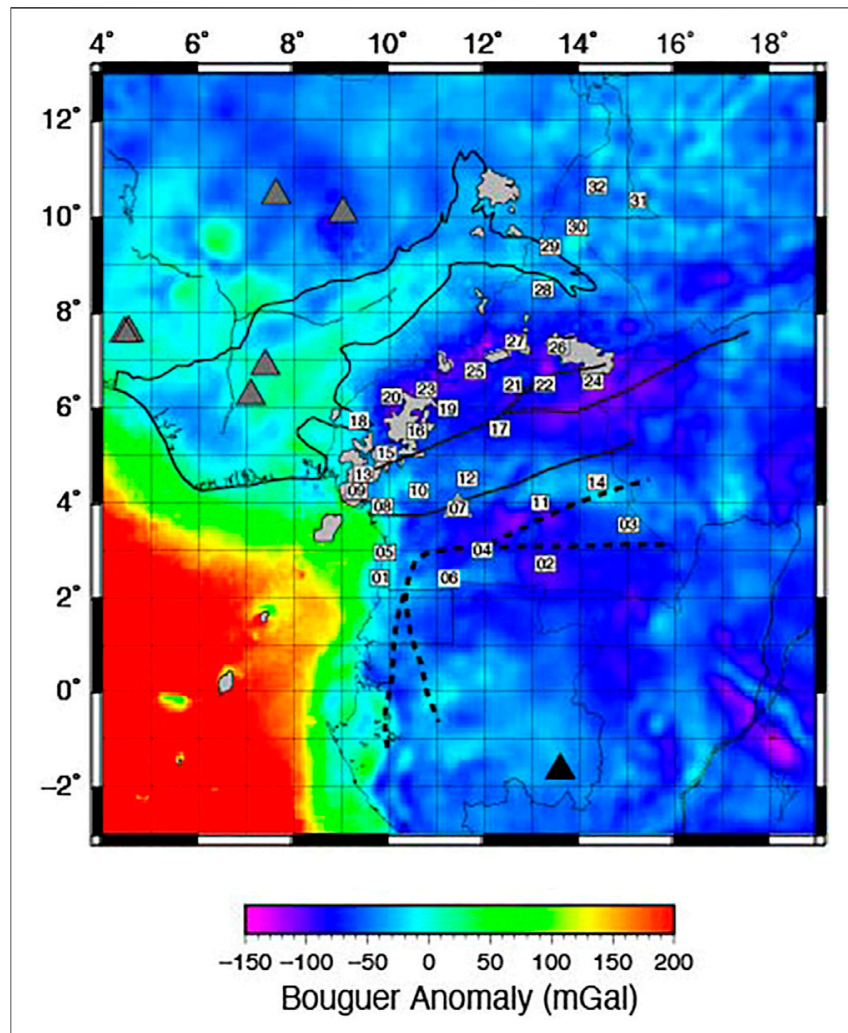

FIGURE 4 | Location of permanent (black triangle = GSN station, Albuquerque Seismological Laboratory/USGS, 1988; dark gray triangles = AfricaArray stations, Penn State University, 2004) and temporary seismic stations (white rectangles $=$ CBSE, Wiens and Nyblade, 2005), superimposed on the bouguer anomaly from the COCE and EGM2008 combined model (GECO; Gilardoni and ReguzzoniSampietro, 2016). Numerical labels indicated station number for the CBSE. Light gray regions indicate volcanic centers, and bold lines show the borders of key regional features (see Figure 1).

of $\mathrm{CO}_{2}$ from the overturning of Lake Nyos (Ambeh et al., 1989; Ambeh and Fairhead, 1991). No seismic activity was observed during or prior to the overturning of Lake Nyos, suggesting the seismic shaking did not contribute to this fatal event (Tabod et al., 1992).

Tabod et al. (1992) compared temporal-spatial patterns in seismicity in and around the CVL from 1982 to 1990 . Seismic activity in this region was primarily associated with Mt. Cameroon, which experienced small magnitude earthquakes, with the largest magnitude during the study time period reaching $\mathrm{m}_{\mathrm{b}}=4.8$. Earthquakes occurred, on average, twice a day near Mt. Cameroon, but typically clustered in earthquake swarms lasting several months. Earthquakes along the northern CVL are more limited. Through the duration of the study, only 200 earthquakes were detected in the northern region, of which only 57 could be located with the seismic networks available at that time (Tabod et al., 1992). These infrequent northern earthquakes, however, included the largest earthquakes recorded during the experiment $\left(\mathrm{m}_{\mathrm{b}} 4.1\right.$ and 4.8 ; Tabod et al., 1992). Tabod et al. (1992) concluded that seismicity associated with the CVL consists of frequent lower magnitude earthquakes
TABLE 1 | Crustal thickness estimates from seismic and gravity studies beneath stations of the CBSE. Tokam = Tokam et al., 2010; Gallacher = Gallacher and Bastow, 2012; Ngalamo = Goussi Ngalamo et al., 2018; Ghomsi = Kemgang Ghomsi et al., 2020.

\begin{tabular}{|c|c|c|c|c|c|}
\hline & \multirow[t]{2}{*}{ Station \# } & \multicolumn{4}{|c|}{ Crustal thickness (km) } \\
\hline & & Tokam & Gallacher & Ngalamo & Ghomsi \\
\hline \multirow[t]{7}{*}{ Adamawa Plateau } & 21 & 35.50 & 34.10 & 34.00 & 39.31 \\
\hline & 22 & 35.50 & 35.80 & 33.00 & 35.27 \\
\hline & 24 & 35.50 & 38.20 & 35.00 & 38.93 \\
\hline & 25 & 38.00 & 38.20 & 39.00 & 34.12 \\
\hline & 26 & 33.00 & 34.90 & 37.00 & 37.80 \\
\hline & 27 & 35.50 & 39.00 & 34.00 & 37.43 \\
\hline & AVERAGE & 35.50 & 36.70 & 35.33 & 37.14 \\
\hline \multirow[t]{3}{*}{ Coastal Plain } & 01 & 28.00 & 37.60 & 42.00 & 27.02 \\
\hline & 05 & 28.00 & 37.40 & 43.00 & 28.40 \\
\hline & AVERAGE & 28.00 & 37.50 & 42.50 & 27.71 \\
\hline \multirow[t]{7}{*}{ Congo Craton } & 02 & 43.00 & 44.60 & 43.00 & 43.21 \\
\hline & 04 & 45.00 & 47.50 & 39.00 & 35.34 \\
\hline & 06 & 45.00 & 41.80 & 42.00 & 30.51 \\
\hline & 07 & 43.00 & 41.80 & 37.00 & 36.47 \\
\hline & 11 & 48.00 & 43.30 & 44.00 & 40.34 \\
\hline & 14 & - & - & 42.00 & - \\
\hline & AVERAGE & 44.80 & 43.80 & 41.17 & 37.17 \\
\hline \multirow[t]{6}{*}{ Northern CVL } & 28 & 30.50 & - & 38.00 & 38.44 \\
\hline & 29 & 25.50 & 25.30 & 26.00 & 32.10 \\
\hline & 30 & 28.00 & 26.50 & 29.00 & 34.38 \\
\hline & 31 & 30.50 & - & 35.00 & 31.30 \\
\hline & 32 & 33.00 & 33.30 & 34.00 & 32.80 \\
\hline & AVERAGE & 29.50 & 28.37 & 32.40 & 33.80 \\
\hline \multirow[t]{6}{*}{ Oubangides } & 03 & 43.00 & 44.60 & 41.00 & 39.96 \\
\hline & 08 & - & - & 38.00 & - \\
\hline & 10 & 38.00 & 35.80 & 37.00 & 37.42 \\
\hline & 12 & 38.00 & 37.80 & 37.00 & 34.33 \\
\hline & 17 & 35.50 & 37.80 & 37.00 & 36.41 \\
\hline & AVERAGE & 38.63 & 39.00 & 38.00 & 37.03 \\
\hline \multirow[t]{9}{*}{ Southern CVL } & 09 & - & - & 30.00 & 34.24 \\
\hline & 13 & 28.00 & 36.50 & 44.00 & 32.28 \\
\hline & 15 & 33.00 & - & 40.00 & 34.99 \\
\hline & 16 & 35.50 & 34.10 & 40.00 & 40.30 \\
\hline & 18 & 30.50 & - & 39.00 & 36.15 \\
\hline & 19 & 35.50 & - & 38.00 & 31.53 \\
\hline & 20 & 33.00 & 33.70 & 36.00 & 37.75 \\
\hline & 23 & 40.50 & 38.30 & 37.00 & 40.02 \\
\hline & AVERAGE & 33.71 & 35.65 & 38.00 & 35.91 \\
\hline
\end{tabular}

near the active Mt. Cameroon, often occurring in swarms, and infrequent higher magnitude earthquakes occurring in the northeastern CVL, possibly associated with the CASZ.

\section{TH CENTURY GEOPHYSICAL STUDIES (2000-2021)}

Recent geophysical studies have focused on the continental portion of the CVL, yielding enhanced views of subsurface structure beneath and near the CVL (e.g., Tokam et al., 2010; Reusch et al., 2010; Reusch et al., 2011; Gallacher and Bastow, 2012; Adams et al., 2015; Goussi Ngalamo et al., 2018; Ojo et al., 2019; Kemgang Ghomsi et al., 2020 and others). These studies were enabled by renewed data collection efforts, including the 
Cameroon Broadband Seismic Experiment (CBSE) lasting from 2005 to 2008 (Wiens and Nyblade, 2005), installation of several permanent seismic stations in and around Cameroon (Penn State University, 2004), and detailed satellite measurements of gravity including the Challenging Minisatellite Payload (CHAMP; Reigber et al., 2002), Gravity Recovery and Climate Experiment (GRACE; Tapley et al., 2004) and Gravity Field and Steady-State Ocean Circulation Explorer (GOCE; Floberghagen et al., 2011) datasets (Figure 4). These higher resolution datasets combined with new modeling techniques led to more detailed models of the lithosphere and the extension of models deeper into the upper mantle beneath the continental portion of the CVL.

\section{Crustal Thickness}

Numerous recent studies have estimated crustal thickness and crustal structure using a wide variety of techniques (Table 1). Using a joint inversion of receiver functions and Rayleigh wave group velocities, Tokam et al. (2010) found that crustal thicknesses beneath the southern and central CVL and the Oubanguides Belt along its southern border are similar $(35-39 \mathrm{~km})$, while thicker crust $(43-48 \mathrm{~km})$ underlies the northern edge of the Congo Craton and thinner crust $(26-31 \mathrm{~km})$ is found beneath rifted regions along the coastal plain and the Garoua rift to the north. These estimates of crustal thickness from receiver functions are broadly similar to those from early 1D velocity models (Stuart et al., 1985) and from gravity studies (e.g., Fairhead and Okereke, 1987; Okereke, 1988), but provide greater spatial coverage and detail. The thick crust beneath the Congo Craton likely represents a crustal suture formed during the amalgamation of Gondwana, while thin crust beneath the Garoua rift and the coastal plains are attributed to the rifting of the Benue trough and the formation of the Atlantic ocean, respectively (Tokam et al., 2010).

Gallacher and Bastow (2012) used teleseismic receiver functions and $\mathrm{H}-\kappa$ analysis to estimate the crustal thickness and velocity structure beneath the CVL. Their patterns in crustal thickness closely follow those indicated by previous studies, with thick crust beneath stations in the Congo Craton, thin crust beneath stations in the Garoua Rift, and moderate crustal thickness beneath the CVL and the Obanguides Belt. Reported crustal thicknesses beneath the stations near the coastal plains is nearly $10 \mathrm{~km}$ thicker than those found by previous studies (e.g., Tadjou et al., 2009; Tokam et al., 2010), but this is likely due to biases induced by the predominance of raypaths traveling through the Congo Craton to the east (Gallacher and Bastow, 2012).

Crustal thickness has also been estimated using modeling of World Gravity Map data (WGM 2012; Goussi Ngalamo et al., 2018) and joint inversion of the Experimental Gravity Field Model (XGM 2016) with topographic and seismic data (Kemgang Ghomsi et al., 2020). Fundamental patterns in crustal thickness estimates from both gravity-based models are similar to those from seismic imaging, exhibiting thicker crust beneath the Congo Craton and thinner crust, with limited variability in thickness, beneath the southern CVL, the Oubangides Belt, and the Adamawa Plateau (Goussi Ngalamo et al., 2018; Kemgang Ghomsi et al., 2020). Numerical averages of crustal thickness within each region, however, show a more complex story and differ from seismic estimates in several ways (see Table 1 for a comparison). Beneath the northern CVL and the Adamawa Plateau, and the Oubangides Belt, crustal thickness estimates are consistent for all studies (Table 1). For the southern CVL, crustal thickness estimates are similar in most studies, with only gravity estimates by Goussi Ngalamo et al. (2018) showing a slight difference averaging $4.5 \mathrm{~km}$. Crustal thickness estimates for the Congo Craton are thinner in both gravity studies than estimates in seismic models. Beneath the coastal plain, Goussi Ngalamo et al. (2018) report crustal thicknesses that are similar to those for Congo Craton, which are greater than those reported for coastal stations by either seismic studies. Kemgang Ghomsi et al. (2020), however, find evidence for thinned crust beneath the coastal plains, consistent with the findings of Tokam et al. (2010), but smaller than estimates from Gallacher and Bastow (2012) or Goussi Ngalamo et al. (2018). Differences between crustal thickness estimates from seismic and gravity modeling may reflect a complex and laterally varying structure, resulting in heterogeneous density structures of the crust.

\section{Crustal Structure}

Average crustal velocities for the Congo Craton are consistent across multiple studies and methodologies, ranging from 3.84 to $3.9 \mathrm{~km} / \mathrm{s}$, comparable to other global cratonic regions (Tokam et al., 2010; Guidarelli and Aoudia, 2016; Ojo et al., 2018; Ojo et al., 2019). The lower crust is characterized by a thick layer with higher velocities greater than $4.0 \mathrm{~km} / \mathrm{s}$ (Tokam et al., 2010; Ojo et al., 2019). Tokam et al. (2010) interpret this high velocity layer as a region of mafic intrusions into the lower crust, however evidence of low $\mathrm{Vp} / \mathrm{Vs}$ ratios throughout the crust alternatively suggests a felsic-to-intermediate crustal composition. Low Vp/Vs ratios (1.76 - Gallacher and Bastow, 2012; 1.73 - Ojo et al., 2019) are consistent with other global cratons exhibiting a TonaliteTrondhjemite-Granodiorite composition (Thompson et al., 2010; Ojo et al., 2019). Furthermore, Ojo et al. (2019) find that Vp/Vs ratios are lower in the middle to lower crust than in the upper crust, suggesting a notable lack of mafic material in the lower crust of the Congo Craton.

Both the southern and northern CVL are characterized by a uniform average crustal shear wave velocity between $3.6-3.8 \mathrm{~km} / \mathrm{s}$ (Tokam et al., 2010; Guidarelli and Aoudia, 2016; Ojo et al., 2018; Ojo et al., 2019) and by low Vp/Vs ratios (Gallacher and Bastow, 2012; Ojo et al., 2019), which together suggest a lack of large-scale mafic intrusions into the lower crust of the CVL or the surrounding Adamawa Plateau. This is a notable difference from the rifted Benue Trough to the north, where gravimetric models indicate the presence of a mafic lower crust (Eyike and Ebbing, 2015). Low Vp/Vs ratios beneath the CVL also suggest that the volcanic line lacks large qualities of crustal melt at present or within the past 1MY (Gallacher and Bastow, 2012; Ojo et al., 2019). Rifts and hot spots from localities around the globe typically display both high elevations supported by the accumulation of mafic lower crust and melt within the crust, reflected in high seismic velocities, gravity, and Vp/Vs ratios (e.g., 


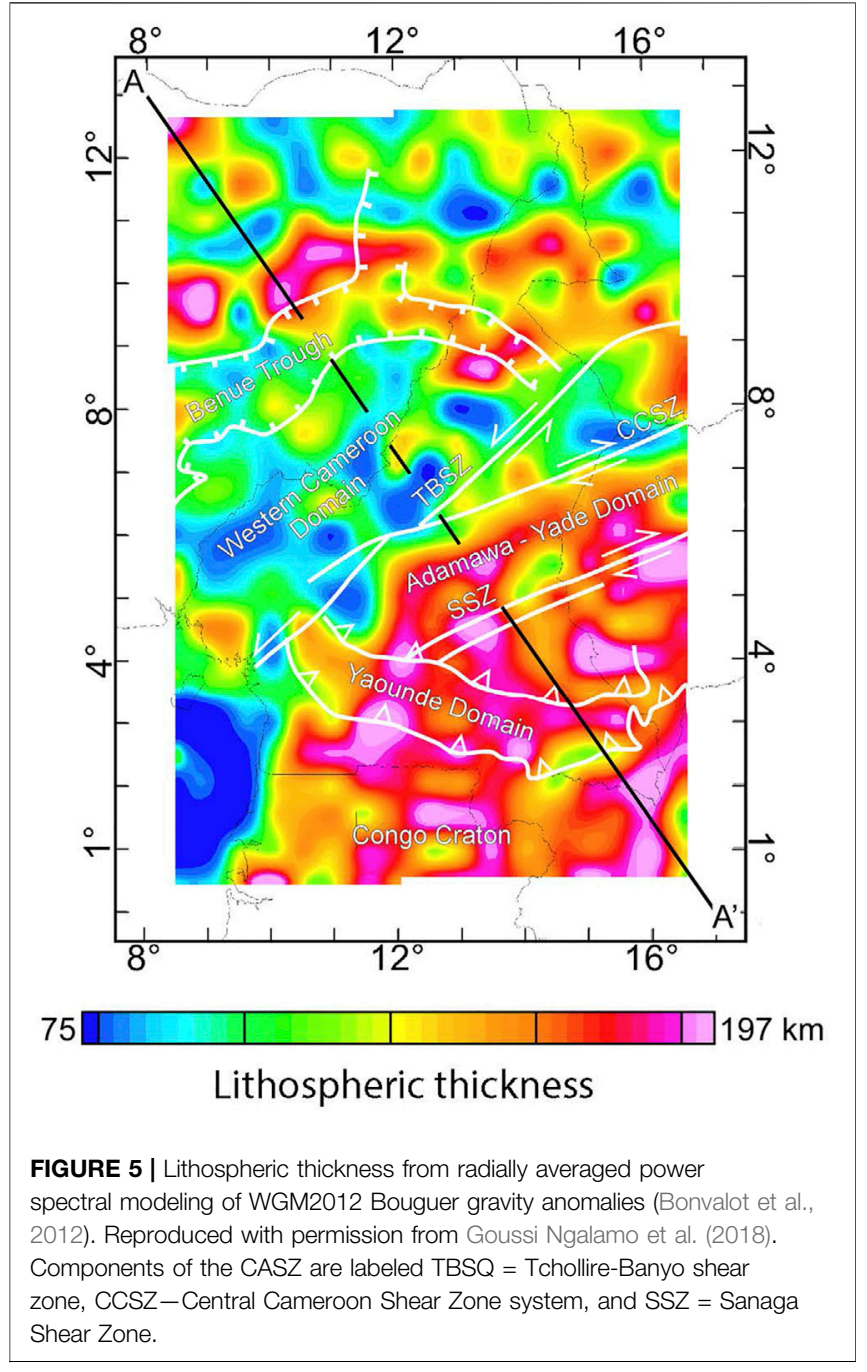

Ebinger et al., 2017). The lack of these properties in the CVL provides support for the hypothesis that the uplift of the CVL and the surrounding Adamawa Plateau is due to thermal anomalies in the upper mantle (e.g., Fairhead and Okereke 1987), which is further supported by geophysical imaging of the upper mantle (see Section 4.3; Gallacher and Bastow, 2012).

Although average crustal structure is broadly consistent along the northern and southern CVL, a few localized deviations are observed. Shear wave velocities beneath several stations within the southern CVL show a thin fast velocity zone at the base of the crust, which is lacking or very thin beneath stations in the northern CVL (Tokam et al., 2010). A similar difference in the northern and southern CVL is observed in average crustal density, with higher density rocks in the southern CVL and the neighboring Oubangides Belt and lower density rocks in the northern CVL, possibly due to the prevalence of granitoid intrusions in that region (Kemgang Ghomsi et al., 2020). Isolated fast velocity layers are also found in the upper crust beneath many stations across Cameroon using joint inversion of receiver functions and surface wave velocities (Tokam et al., 2010). Similarly, ambient noise tomography shows a region of fast velocities in the upper to mid-crust around $5^{\circ} \mathrm{N}$ and $10.5^{\circ} \mathrm{E}$ (Guidarelli and Aoudia, 2016). These isolated fast velocity layers and bodies may reflect mafic intrusions into the shallow crust associated with CVL volcanism (Tokam et al., 2010; Guidarelli and Aoudia, 2016). Finally, the regions immediately surrounding Mt. Cameroon exhibit pronounced low surface wave velocities, which likely reflect ongoing magmatic processes at depth, as suggested by high rates of seismicity restricted to this region (Tabod et al., 1992; De Plaen et al., 2014; Guidarelli and Aoudia, 2016).

\section{Lithospheric and Mantle Structure}

Lithospheric thickness and structure vary dramatically across the areas surrounding the CVL. The Congo Craton is characterized by a thick lithosphere with high seismic velocities. Spectral analysis of Bouguer anomalies indicate a lithospheric thickness of $150-200 \mathrm{~km}$ for the Congo Craton and the Oubangides Belt, with a thinner lithosphere beneath the CVL, ranging from 113 to $162 \mathrm{~km}$ (Figure 5; Goussi Ngalamo et al., 2018). Shear wave velocities derived from regional Rayleigh wave tomography yield a similar estimate for lithospheric thickness beneath the Congo Craton and the Oubangides Belt of 175-200 km (Adams et al., 2015). Beneath the CVL, however, shear wave velocities in this model are greatly reduced at depths greater than $50 \mathrm{~km}$ in the southern CVL and $75 \mathrm{~km}$ in the northern CVL, indicating either a thermally eroded or thinned and altered lithosphere for the CVL (Adams et al., 2015). Analysis of continental scale shear wave velocity models also suggests greatly reduced lithospheric thicknesses of $72-133 \mathrm{~km}$ beneath the CVL (Sebai et al., 2006; Fishwick, 2010). These differences between gravity and seismic based lithospheric thicknesses are a reflection of the different physical properties measured by the methods. It is possible that these differences may reflect substantial variations in sublithospheric structure not included in gravity modeling (seismic evidence suggests substantial sublithospheric heterogeneity within the region, see below), or alternatively the velocity reduction at $50-75 \mathrm{~km}$ in seismic models may indicate thermal alteration but not erosion of the lithosphere at greater depths. All models, however, note significantly thinner lithosphere beneath the CVL when compared to the Congo Craton and Oubangides Belt to the south.

Low seismic velocities beneath the CVL continue deeper into the upper mantle. Teleseismic body wave tomography reveals a vertical, tabular low velocity zone directly beneath the CVL extending to at least $300 \mathrm{~km}$, in which $\mathrm{P}$-wave velocities are reduced $-1-2 \%$ and $S$-wave velocities are reduced $-2-3 \%$ compared to the regional average, with maximum velocity reduction at $200 \mathrm{~km}$ (Figure 6A; Reusch et al., 2010). The Congo Craton has fast velocities (>+2\% Reusch et al., 2010). Shear wave velocities derived from Rayleigh wave tomography show a very similar pattern, with a tabular-shaped region in which velocities are reduced up to $-5.5 \%$ beneath the CVL and positive velocity anomaly of up to $5 \%$ beneath the Congo Craton, when compared to the mobile belts in the region (Figure 6B; Adams et al., 2015). Adams et al. (2015) observe maximum velocity reduction at depths of $70-120 \mathrm{~km}$, slightly shallower than the depth of maximum velocity reduction found by body wave tomography, which may be exhibit small amounts of 

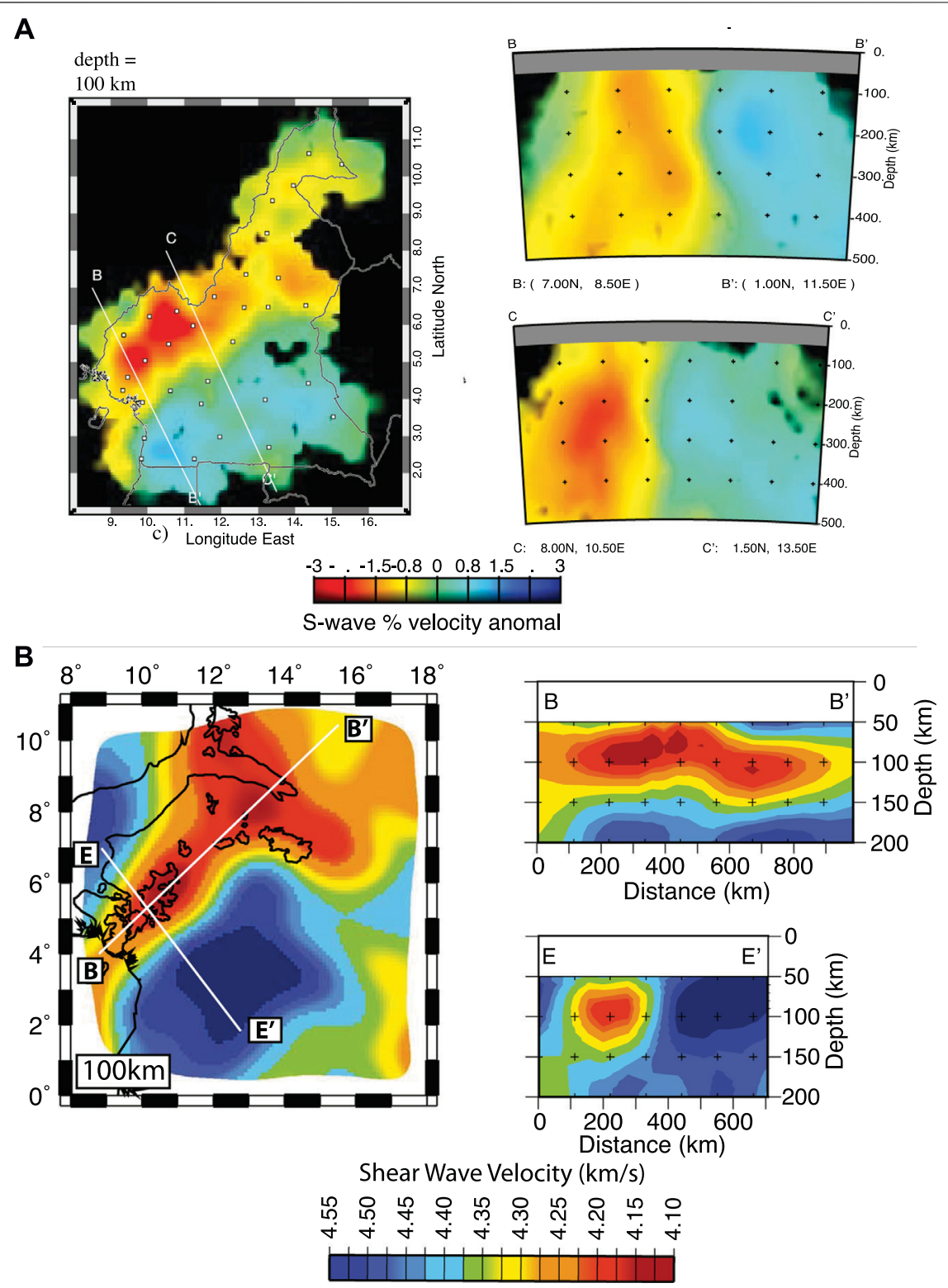

Shear Wave Velocity $(\mathrm{km} / \mathrm{s})$

FIGURE 6 | Tomographic models. (A) A $100 \mathrm{~km}$ depth slice and selected cross-sections from an S-wave body wave tomography model (adapted with permission from Reusch et al., 2010). (B) A 100 km depth slice and selected cross-sections from an S-wave model derived from Rayleigh wave tomography (adapted with permission from Adams et al., 2015).

vertical smearing from the vertically oriented body waves (Reusch et al., 2010). Both of these tomography models that extend to sublithospheric depths find a sharp vertical transition between the CVL and the Congo Craton, extending into the asthenosphere to at least $200 \mathrm{~km}$ (Adams et al., 2015) or $300 \mathrm{~km}$ (Reusch et al., 2010). Neither study finds evidence of reduced mantle velocities beneath other regions of the Adamawa Plateau as suggested by earlier smaller-scale tomographic models (Dorbath et al., 1986). These regional findings by Reusch et al. (2010) and Adams et al. (2015) are consistent with larger-scale, lower resolution continental tomography studies, which also suggest that low velocities below the CVL are isolated to the shallow mantle (e.g., Sebai et al., 2006; Fishwick, 2010; Emry et al., 2019).
Receiver function analysis of the mantle transition zone indicates a transition zone with a typical thickness, suggesting that the low velocity anomaly beneath the CVL does not extend to the transition zone or into the lower mantle (Reusch et al., 2011). Some studies note the presence of low velocities in the deep mantle $(>1,000 \mathrm{~km})$ beneath the CVL (e.g., French and Romanowicz, 2015). Tomographic evidence restricting low velocities to depths less than $300 \mathrm{~km}$ (e.g., Reusch et al., 2010; Adams et al., 2015) together with a thermally unperturbed mantle transition zone (Reusch et al., 2011), however, show that this lower mantle feature is not directly connected to the CVL. It may instead be associated with the broader African Superplume. 


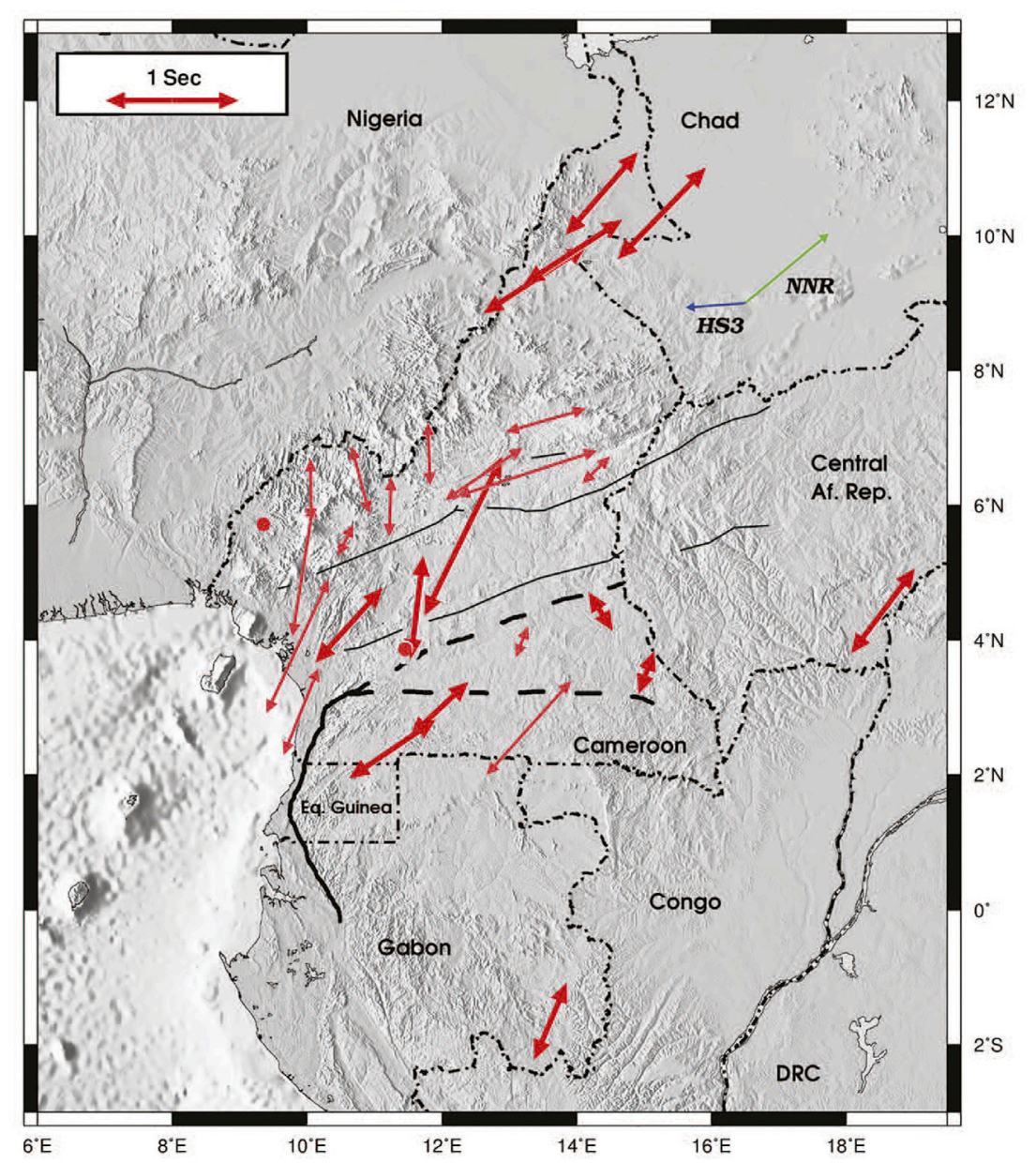

FIGURE 7 | Fast directions and delay times from shear wave splitting for stations from the CBSE. Reproduced with permission from Koch et al. (2012).

\section{Insights From Anisotropy}

Several studies have used shear wave splitting to investigate azimuthal anisotropy beneath the CVL and surrounding regions. While the observed patterns in these studies are broadly similar, the interpretations and implications for the formation of the CVL differ tremendously. Koch et al. (2012) found a NE-SW fast direction with split times of approximately $1 \mathrm{~s}$ beneath the Congo Craton and the northern CVL, and a N-S fast direction with split times of approximately $0.7 \mathrm{~s}$ beneath the southern CVL. The CVL and the Congo Craton are separated by a region with variable orientations and low delay times (Figure 7). Elsheikh et al. (2014) found generally similar spatial patterns in the orientation fast propagation. Notable deviations in fast direction were noted at only five stations, but differences at these stations did not affect the overall spatial patterns. Elsheikh et al. (2014) did, however, observe greater delay times that averaged twice those observed by Koch et al. (2012). De Plaen et al. (2014) find orientations of fast directions and delay times for stations in the Congo Craton and the northern CVL that are similar to those found by Koch et al. (2012). Beneath the southern CVL and the Oubangides Belt, they find only null solutions. De Plaen et al. (2014) note, however, that these null stations typically have very low delay times $(<0.53 \mathrm{~s})$ in Koch et al. (2012). Thus, all studies observe fast directions oriented NE-SW in the Congo Craton and the northern CVL, with a great range of delay times. There is a lack of consensus for the patterns of anisotropy beneath the southern CVL, as observations differ significantly with one study finding N-S orientations with large delay times (Elsheikh et al., 2014), one study finding N-S orientations with small delay times (Koch et al., 2012), and another study finding null results within the southern CVL (De Plaen et al., 2014).

Interpretations of the implications for the formation of the CVL are similarly variable including 1) northeastern sublithospheric flow resulting in thinned lithosphere (Elsheikh et al., 2014), 2) small-scale asthenospheric convection (Koch et al., 2012), and 3) strong vertical flow from asthenospheric convection or a plume resulting in high radial anisotropy and low azimuthal anisotropy (De Plaen et al., 2014).

An anisotropic velocity model from ambient noise and earthquake Rayleigh waves indicates complex multi-layered anisotropy in this region (Ojo et al., 2018). This tomographic 

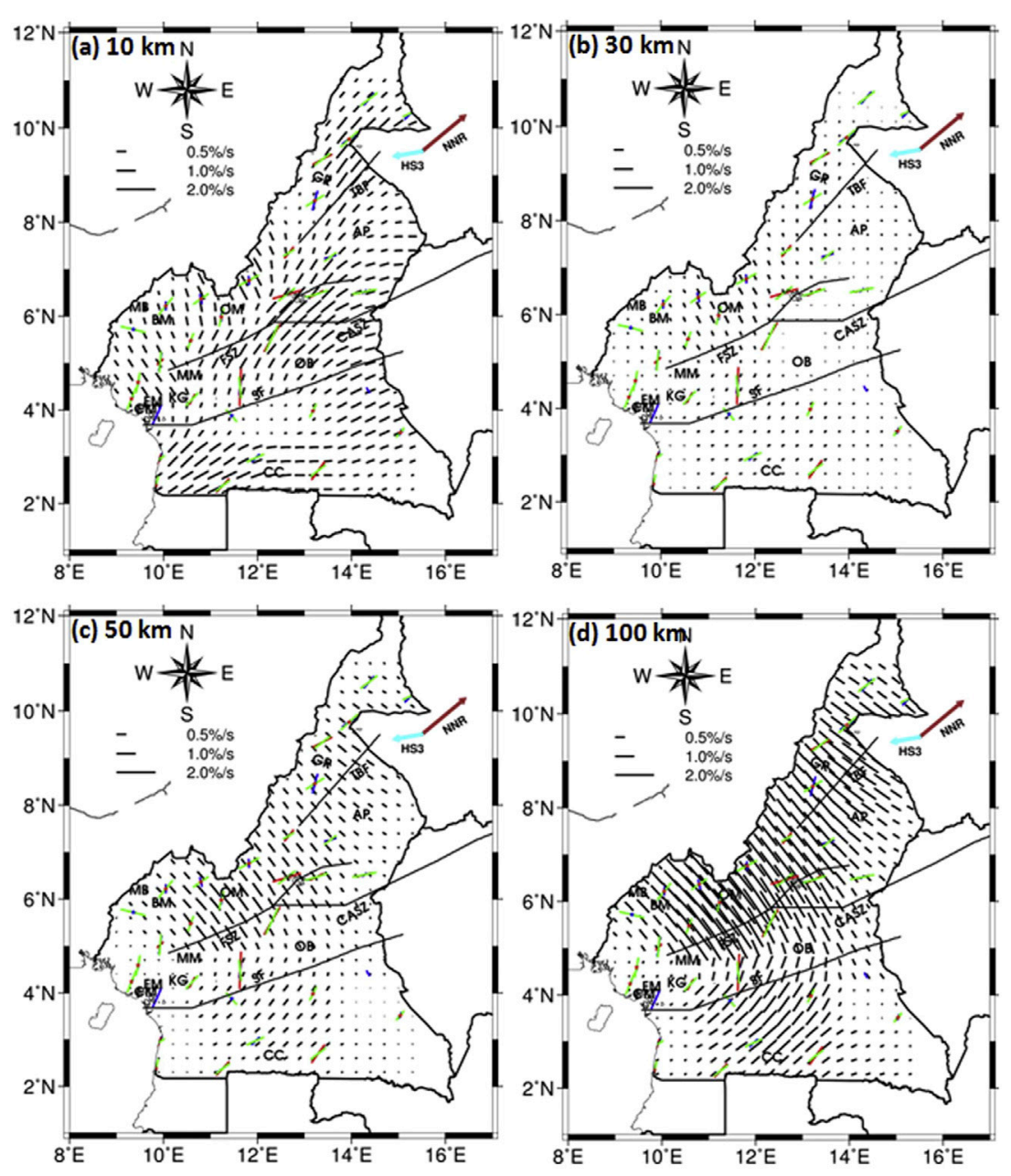

FIGURE 8 | Anisotropic fast directions within Cameroon. Black lines show azimuthal anisotropy from Rayleigh wave tomography at $10 \mathrm{~km}$ (A), $30 \mathrm{~km}$ (B), $50 \mathrm{~km}$ (C), and $100 \mathrm{~km}$ (D). Blue, red, and green lines show anisotropy from shear wave splitting from (Koch et al., 2012), De Plaen et al. (2014), and Elsheikh et al. (2014) respesectively. Reproduced with permission from Ojo et al. (2018).

model of anisotropy shows 1) strong NE-SW fast direction at a depth of $10 \mathrm{~km}$ through most of the study region, with weak N-S or NW-SE anisotropy in the southern CVL, 2) a primarily isotropic lower crust, and 3) strong anisotropy in the lithospheric mantle, oriented NW-SE in the northern and central CVL, NE-SW in the Congo Craton, and null to NW-SE orientations in the southern CVL near Mt. Cameroon (Figure 8). This observed change in fast directions with depth is supported by average regional anisotropy from Rayleigh wave tomography, which shows a change in average fast direction from NNE-SSW at periods less than $50 \mathrm{~s}$ to NW-SE at periods greater than $110 \mathrm{~s}$ for the CVL (Adams et al., 2015). These finding are consistent with those from shear wave splitting by Koch et al. (2012) at crustal depths but are inconsistent at lithospheric mantle depths for the northern and central CVL. This suggests that measured anisotropy beneath the Congo Craton and the southern CVL may derive exclusively from the lithosphere, but that there must be a significant contribution from the lower lithosphere or asthenosphere in the central and northern CVL, which is not constrained by the model of Ojo et al. (2018).

\section{Plate Motions}

Some studies have suggested that the CVL may be undergoing extension, forming a rift similar to the now dormant Benue Trough or the early stages of rifting in the East African Rift System (e.g., Fairhead and Okereke, 1987; Okereke, 1988). Geodetic studies are limited in this region, but analysis of GPS and Doppler orbitography and radiopositioning integrated by satellite (DORIS) across the African continent finds that plate motions near the CVL are best fit by a single Nubian plate, without evidence for a microplate boundary at or near the CVL (Saria et al., 2013).

\section{Seismicity}

Recent studies of seismicity near the CVL built upon studies from the 1980s and 1990s (Section 3.3), using the expanded CBSE seismic network and more numerous permanent stations deployed in the early 2000s. Analysis of five months of continuous seismic data from the CBSE, found 203 earthquakes with magnitudes between 1.4-4 $\mathrm{M}_{\mathrm{L}}$ (De Plaen 


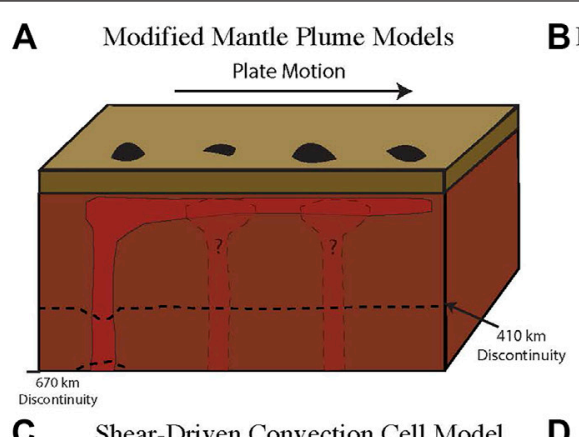

B Pre-Existing Lithospheric Weakness Model

C Shear-Driven Convection Cell Model
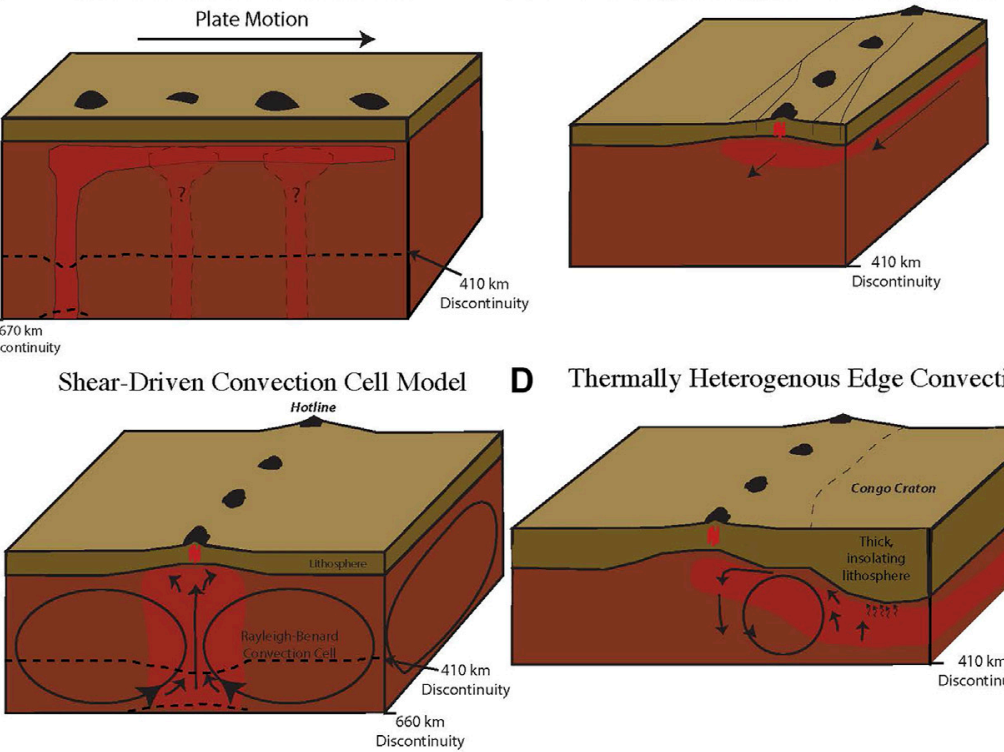

D Thermally Heterogenous Edge Convection
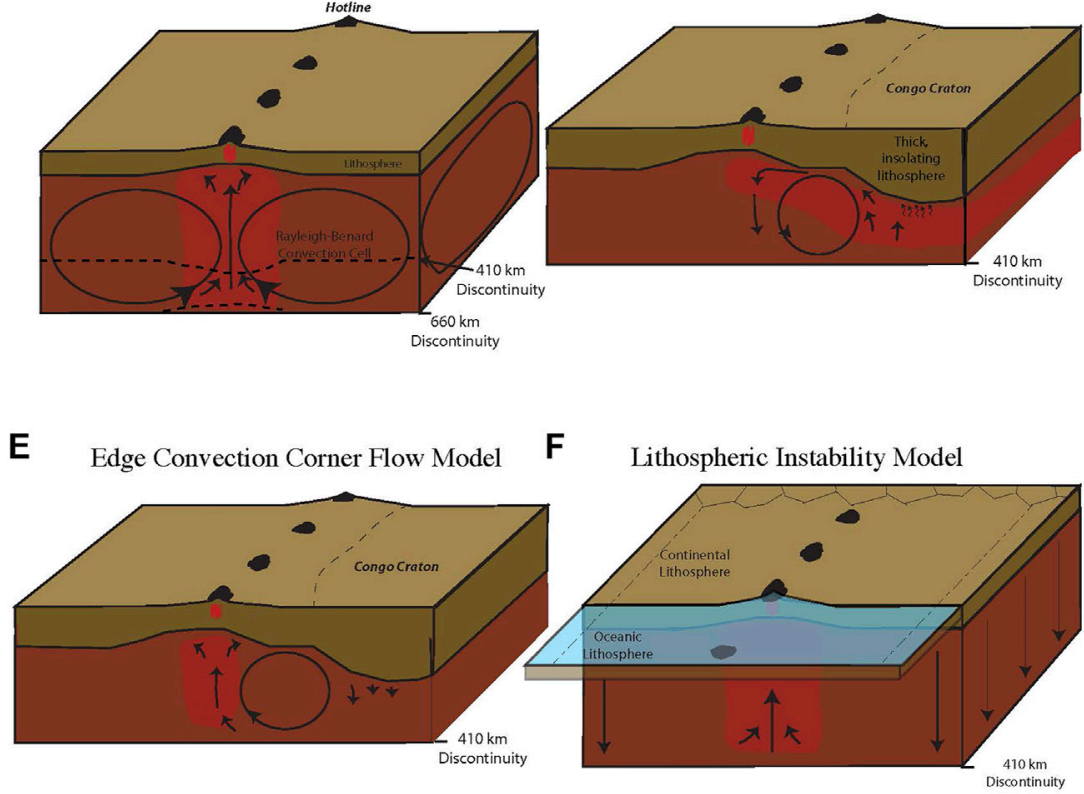

FIGURE 9 | Geodynamic models for the formation of the CVL, included modifications of mantle plume trace (A), diversion of material along the CASZ (B), convection driven by shear along the base of the transition zone (C), convection driven by thermal contrasts combined with contrasts in lithospheric thickness (D), convection driven by contrasts in lithospheric thickness in a thermally homogenous mantle (E), and lithospheric instabilities driven by the juxtaposition of oceanic and continental lithosphere (F) after Adams et al. (2015).

et al., 2014). Of these events, three-quarters were centered around Mount Cameroon, and the rest lay in a roughly linear swath between Bioko and Mount Cameroon, aligned with the strike of the CVL. Away from this region, which has exhibited recent volcanic activity, the rest of the CVL and surrounding region appears largely aseismic. The spatial distribution of earthquakes during this study are consistent with seismicity studies from the previous decade, although a lower average rate of seismicity was recorded during this more recent study, despite the broader seismic array available for detection (Tabod et al., 1992; De Plaen et al., 2014). The majority of earthquakes nucleated in the upper $15 \mathrm{~km}$ and exhibited low frequency contents and emergent arrivals, suggesting they derived from magma or volatile migration in the upper crust. A small number of earthquakes were detected along the eastern and southern flanks of the Mount Cameroon at depths of $25-30 \mathrm{~km}$, suggesting magmatic activity at these depths associated with the active volcano (De Plaen et al., 2014). The association of seismicity in the CVL with regions of active volcanism differs from earthquake distributions in continental rifts (e.g., Mulibo and Nyblade, 2013; Ebinger et al., 2017), and suggests that the CVL is not undergoing rifting as suggested by some early studies (e.g., Okereke, 1988).

\section{GEODYNAMIC MODELS FOR FORMATION}

Numerous models have been proposed for the formation of the CVL. Some models have proven untenable as new or improved evidence arises. For example, early speculation that the CVL might represent a simple Wilson-Morgan style mantle plume (e.g., Morgan, 1983; Van Houten, 1983; Lee et al., 1994; Burke, 2001) have generally been dismissed due to the lack of age progression along the line. Similarly, speculation that the CVL represents an early stage rift (e.g., Fairhead and Okereke, 1987; Okereke, 1988) now appears unlikely due to the lack of discernable extension from GPS measurements (e.g., Saria et al., 2013). Other models remain in circulation, and typically 
invoke modifications to a simple plume model, mantle convection, and/or interaction between the asthenospheric and lithospheric mantle. The most prominent of these hypotheses for formation, their implications for crust and mantle structure, and evaluations based on existing geophysical data are discussed below and illustrated in Figure 9.

\section{Modified Mantle Plume Origin}

Lack of age progression along the CVL makes the formation of this feature by a Wilson-Morgan plume unlikely, however, other characteristics of the CVL show similarities to mantle plumes and many studies continue to attribute the formation of the CVL to a mantle plume. For example, Steinberger (2000) suggests that a non-stationary plume moving in the same direction as plate motion might lead to a lack of age progression along the CVL and other African volcanic centers, while also acknowledging the possible role of other mechanisms. A recent whole-mantle velocity model categorizes the CVL as a "clearly resolved" plume based on shear wave velocity perturbations in the lower most mantle (French and Romanowicz, 2014; 2015). Still other studies suggest that the CVL might be formed by multiple mantle plumes, with volcanic material from one plume overprinting material from other plumes and concealing any age progression (Ngako et al., 2006; Njome and Wit, 2014), similar to the multipleplume hypothesis that has been suggested for volcanic lines in the south Pacific (Figure 9A; see Section 2.3). These adapted plume models, however, are inconsistent with seismic and gravimetric data beneath the continental section of the CVL, which indicate a linearshaped upper mantle anomaly, restricted to the upper $200-300 \mathrm{~km}$ (e.g., Okereke, 1988; Poudjom Djomani et al., 1995; Reusch et al., 2010; Adams et al., 2015; Goussi Ngalamo et al., 2018), with no evidence for perturbation of the mantle transition zone beneath the continental portion of the CVL (Reusch et al., 2011). Anisotropic measurements are complex and vary both laterally and with depth (e.g., Ojo et al., 2018), and do not display spatially consistent patterns expected for mantle plumes. Current geophysical models cannot, however, constrain the presence or absence of a mantle plume or plumes for the offshore portions of the CVL.

Other studies suggest that the CVL is formed though the complex interactions between a mantle plume and lithospheric structures associated with the CASZ. The most prominent of these models is the suggested diversion of material produced by the Afar plume in eastern Africa through the CASZ to the CVL (Figure 9B; Ebinger and Sleep, 1998). This model, however, should create a progression in the age of initiation of volcanism, although not for cessation of volcanism, with the oldest volcanic centers in the east and younger volcanic centers in the west, which is not observed along the continental sector (see Figure 2 and references therein). The linear nature of the mantle low velocity zone tomographically imaged beneath the CVL (e.g., Reusch et al., 2010; Adams et al., 2015) is consistent with the sublithospheric thermal anomaly expected for this model. The inconsistency of azimuthal anisotropy (e.g., Koch et al., 2012; De Plaen et al., 2014; Elsheikh et al., 2014) and the change to a NWSE fast orientation at mantle depths (Adams et al., 2015; Ojo et al., 2018), however, are inconsistent with the along-strike sublithospheric flow described in these models.

\section{Upwelling From Shear Driven Convection Cells}

Meyers et al. (1998) noted that many volcanic centers on the African Plate, including the CVL, can be projected into parallel lines stretching across the plate, evenly spaced approximately $1800 \mathrm{~km}$ apart and oriented in a northeast-southwest direction. Volcanic centers within these projected lines share characteristics with the CVL, including a lack of age progression and an apparent uplift along-axis. These observations led Meyers et al. (1998) to hypothesize that these "hot-lines" observed across the African Plate, including the CVL, were formed by intermediate-scale convective rolls within the upper mantle. This proposed mechanism builds upon prior studies that predict cylindrical Rayleigh-Baynard convection cells with alternating convective directions may be generated by shearing at the base of the lithosphere in the presence of fast plate motion (Richter, 1973; Richter and Parsons, 1975). Because the motion of the Nubian Plate is slow, however, such convective rolls generated by shear at the base of the lithosphere would require more than $200 \mathrm{Ma}$ to form (Meyers et al., 1998). Meyers et al. (1998) propose a variation on this mechanism, in which convective rolls are instead produced by shear along the base of the mantle transition zone, with limited shear at the base of the lithosphere. In this proposed model, the CVL and other hotlines are formed at the convergence of two convective rolls (Figure 9C). Due to the alternation of convective directions, the two rolls would converge to form a large linear mantle upwelling, and a corresponding thermal anomaly, extending from the base of the transition zone to the base of the lithosphere (Meyers et al., 1998).

The tabular nature of the mantle low velocity zone imaged beneath the CVL (e.g., Reusch et al., 2010; Adams et al., 2015) and the thinning of the lithosphere (e.g., Okereke, 1988; Poudjom Djomani et al., 1995; Fishwick, 2010; Adams et al., 2015; Goussi Ngalamo et al., 2018) are consistent with the linear upwelling predicted by this model. The isolation of low velocities to the upper 200-300 km imaged by seismic tomography (Reusch et al., 2010; Adams et al., 2015) and the lack of perturbation to the mantle transition zone in receiver function studies (Reusch et al., 2011), however, suggest that no thermal anomaly extends into the transition zone as predicted by this model.

\section{Edge Convection Driven by the Congo Craton}

An alternate group of models attribute the formation of the CVL to edge convection along contrasts in lithospheric thicknesses. In one such model, King and Anderson (1995) suggest that a thick and insulating lithosphere, such as that which may exist beneath the Congo Craton, may lead to asthenospheric heating in the sublithospheric mantle. This thermally buoyant material would then flow laterally at shallow depths to the adjacent thinner lithosphere beneath the CASZ. This higher temperature mantle material would then lead to the formation of volcanism near the juxtaposition of thick and thin lithosphere, similar to the location of the CVL just north of the edge of the Congo 
Craton. This thermally heterogeneous mechanism would produce a thermal anomaly dipping from shallow depths beneath the CVL to deeper depths at the base of the lithosphere beneath the Congo Craton to the south (Figure 9D).

The thermal convection model of King and Anderson (1995) was later expanded to consider the role of initial mantle temperatures on edge convection based on contrasts in lithospheric thickness (King and Anderson, 1998). King and Anderson (1998) demonstrated that the style and orientation of convection induced at an abrupt change in lithospheric thickness is strongly dependent on the thermal conditions of the sub-lithospheric mantle. If the sub-lithospheric mantle is warmed due to insulation by the thick cratonic lithosphere, convection flows laterally at shallow depths from beneath the thicker lithosphere to the thinner lithosphere, where non-erupted material cools and sinks, as described by King and Anderson (1995). If the sub-lithospheric mantle is not thermally perturbed beneath the thicker lithosphere, convection is induced in the opposite direction, with a downwelling beneath the thicker lithosphere and a corresponding upwelling beneath the thinner lithosphere (King and Anderson, 1998). Based on this model, if the asthenosphere beneath the Congo Craton has not been heated by thermal insulation, a corner flow edge should form, with a downwelling directly beneath the Congo Craton and a corresponding upwelling beneath the CVL, forming verticallyoriented thermal anomaly directly beneath the CVL (Figure 9E; King and Ritsema, 2000).

Both edge convection models would produce a shallow thermal anomaly, restricted to the upper few hundred kilometers of the upper mantle, which is consistent with findings from seismic tomography (Reusch et al., 2010; Adams et al., 2015) and transition zone receiver functions (Reusch et al., 2011). The shapes and lateral extent of the anomalies, however, would differ between the two models. In the thermally heterogeneous model of King and Anderson (1995), the thermal anomaly would be tilted, at shallow mantle depths beneath the CVL and reaching deeper depth beneath the Congo Craton (Figure 9D). This is not supported by tomographic evidence, which indicates a vertically oriented low velocity zone directly beneath the CVL (Reusch et al., 2010; Adams et al., 2015) nor by gravimetric models, which indicate that density anomalies are restricted beneath the CVL (e.g., Okereke, 1988; Poudjom Djomani et al., 1995; Goussi Ngalamo et al., 2018). Existing geophysical evidence instead supports the vertically oriented thermal upwelling predicted by the corner flow model (Figure 9E; King and Anderson, 1998; King and Ritsema, 2000).

\section{Continental and Oceanic Lithosphere Instability}

The impacts of lithospheric contrasts on convection were reexamined using analog models in a study by Milelli et al. (2012). Milelli et al. (2012) build upon prior experimental results demonstrating that a system that is heated from below and cooled from above, such as the heating of the lithosphere from the mantle and cooling at the surface boundary layer, forms a system of hexagonal convection cells (Jaupart et al., 2007). Milelli et al. (2012) modified this system to include a step-change in the thickness of the lid being heated from below and cooled from above, with a thick lid surrounded by a thinner lid, mimicking the contrast between oceanic and continental lithosphere. In this scenario, a complex system of convective cells was produced. Within the thick-lidded interior representing continental lithosphere, hexagonal convection cells formed as in prior studies (Jaupart et al., 2007). Near the change in lid thickness representing the continental margin, however, these hexagonal cells transition to linear convection cells, radiating outwards from the thicker simulated continental interior (Milelli et al., 2012). This model predicts that the contrast between thick continental lithosphere and thin oceanic lithosphere should produce upwellings and downwelling at and perpendicular to continental margins. Milelli et al. (2012) describe this system as a lithospheric instability, and propose the CVL as an example of this complex convective system, with the interior "Y" shape of the CVL indicating the boundary between hexagonal and linear convective cells (Figure 9F). This model would produce a vertically oriented thermal anomaly, restricted to the upper mantle, where upwellings occur, similar in shape to that predicted by the corner flow model (King and Anderson, 1998) but driven by the contrast in the lithospheric thickness beneath the continental and oceanic lithosphere instead of by the contrast between the lithosphere of the Congo Craton and the Oubangides Belt (Milelli et al., 2012). This model is equally supported by geophysical imaging of a shallow, vertically oriented, tabular upper mantle anomaly described in section 5.3 (Okereke, 1988; Poudjom Djomani et al., 1995; Reusch et al., 2010; Reusch et al., 2011; Adams et al., 2015; Goussi Ngalamo et al., 2018).

\section{DISCUSSION AND KEY QUESTIONS}

Geophysical studies have given numerous insights into the crust and upper mantle structures of the CVL and surrounding areas during the past 40 years. Studies have revealed regional patterns in crustal thickness and structure, with thinned crust beneath the Benue Trough, thicker crust beneath the Congo Craton, and a generally consistent crustal thickness for the CVL and the surrounding Oubangides Belt, with some disagreement between studies on the relative thickness of stations along the coastal plain.

The crust of the Congo Craton displays velocities and Vp/Vs ratios characteristic of other Archean Cratons (Tokam et al., 2010; Guidarelli and Aoudia, 2016; Ojo et al., 2018; Ojo et al., 2019), although the potential existence of mafic intrusions into the lower-most crust is debated (Tokam et al., 2010; Gallacher and Bastow, 2012; Ojo et al., 2019). The northern and southern CVL are both characterized by low crustal bulk velocities and low $\mathrm{Vp} / \mathrm{Vs}$ ratios, suggesting a lack of large-scale mafic intrusions into the crust (Tokam et al., 2010; Gallacher and Bastow, 2012; Guidarelli and Aoudia, 2016; Ojo et al., 2018; Ojo et al., 2019), while a decrease in crustal density is observed for the northern CVL, likely reflecting the increasing prevalence of granitoid 
intrusions in that region. Localized high velocity layers and pockets across the CVL and the Adamawa Plateau may reflect small-scale intrusion of mafic materials into those regions (Tokam et al., 2010; Guidarelli and Aoudia, 2016). Offshore, crustal thickness remains constant, with uplift accommodated by lithospheric bending (Meyers et al., 1998).

Unlike the consistent crustal thickness observed beneath the Adamawa Plateau, both gravimetric (Goussi Ngalamo et al., 2018) and seismic studies (Fishwick, 2010; Adams et al., 2015) indicate substantially thinner lithosphere beneath the CVL, although the degree of thinning differs between methods. Thinned lithosphere beneath the continental CVL is underlain by a vertical, linear anomaly of low velocities, which extends to $200-300 \mathrm{~km}$ (Reusch et al., 2010; Adams et al., 2015) with no evidence for anomalies in the transition zone (Reusch et al., 2011). Studies of shear wave splitting indicate NE-SW fast directions beneath the northern CVL and N-S or null measurements beneath the southern CVL, with the relative contributions of crustal, lithospheric mantle, and sublithospheric mantle varying across the region (Koch et al., 2012; De Plaen et al., 2014; Elsheikh et al., 2014; Ojo et al., 2018). The causes of azimuthal anisotropy remain debated between studies. Neither deep lithospheric and sublithospheric mantle structure nor anisotropy is modeled for the oceanic portion of the CVL.

The CVL has displayed only low levels of small magnitude $\left(<4.8 \mathrm{M}_{\mathrm{b}}\right.$ ) seismicity since monitoring began using local stations in the 1980s. Seismicity is primarily concentrated around the active volcanic center of Mt. Cameroon, where lower magnitude earthquakes primarily nucleate in the upper $15 \mathrm{~km}$, appearing in swarms likely associated with migration of volatiles and magma (Tabod et al., 1992; De Plaen et al., 2014). Smaller numbers of earthquakes are detected in the northern portion of the CVL, but these infrequent earthquakes have a slightly higher average magnitude (Tabod et al., 1992).

The observed geophysical characteristics allow evaluation of the numerous geodynamic models that have been proposed for the formation of the CVL. The linear nature of the upper mantle low velocity anomalies, their restriction to the uppermost mantle, and the orientations of seismic anisotropy suggest a lack of mantle plume activity at the CVL, at least beneath the continental sector. Similarly, the restriction of the low velocities to the upper most mantle indicate that the CVL is not formed by shear at the base of the transition zone, and the vertical nature of the low velocity anomaly is inconsistent with edge convection driven by thermal heterogeneities in the sublithospheric mantle. The rapid spatial variation in azimuthal anisotropy (e.g., Koch et al., 2012; De Plaen et al., 2014; Elsheikh et al., 2014) and the NW-SE fast orientation at mantle depths (Adams et al., 2015; Ojo et al., 2018) are inconsistent with models of channelized sublithospheric flow. Current evidence suggests that the most likely models for the formation of the continental CVL are corner flow edge convection (King and Anderson, 1998) or lithospheric instability (Milleli et al., 2012).

The mantle structure of the oceanic CVL, however, remains largely unexplored except through continental or global scale models. Some large scale models suggest that first order structures observed onshore may continue offshore (e.g., Sebai et al., 2006;
Fishwick, 2010), while others suggest a change in structure offshore (e.g., Hansen et al., 2012), but resolution is limited in these large-scale models. The detailed structure of the offshore CVL remains an important unresolved question, with key implications for the mechanisms forming and influencing the CVL. For example, no evidence is seen onshore for age progression from a mantle plume, yet there is some evidence for age progression offshore (see Figure 2). The lack of geophysical models for the mantle offshore means that it is possible that the offshore portion of the CVL could be formed or influenced by a mantle plume, giving the overall CVL a complex geodynamic history, in which the oceanic and continental sectors are formed by separate mechanisms. This possibility is supported by studies that resolve low velocities in this region within the deep mantle (e.g., French and Romanowicz, 2015). On the other hand, the two primary candidate models for the formation of the continental CVL, corner flow edge convection (King and Anderson, 1998) and lithospheric instability (Milelli et al., 2012), would likely produce different offshore structures in the mantle, with convective flow following the curve of the Congo Craton at depth for the corner flow model or continuing to extend perpendicular to the coast for the lithospheric instability model.

Additional first-order questions also remain for the onshore CVL. No study, for example, has found a causal link between the Benue Trough and the CVL that is consistent with both geological and geophysical evidence. Thus, uncertainty remains about the cause of the characteristic Y-shape shared by the neighboring features. Similarly, although the proximity and similar azimuth of the CVL and the CASZ are compelling, no consensus has been reached regarding the degree of influence held by the preexisting CASZ on the formation of the CVL.

Finally, while the geophysical studies of the past 40 years have yielded tremendous insights into the crust structure and onshore mantle structure of the CVL, these finding have in turn led to new questions. For example, several differences are observed in crustal and upper mantle velocity structure and density for the southern and northern continental CVL, yet these regions share a similar eruptive history and are presumed to have formed from the same mechanism. Therefore, what are the causes for these differences in structure? Measurements of anisotropy are often inconsistent between studies and variable at short distances within studies, and there is evidence for significant changes in anisotropic structure with depth. So, what are the causes of anisotropy in this region and why does it vary rapidly in three dimension? And, two of the leading candidate models for the formation of the continental CVL are dependent on the rapidly changing lithospheric thickness at the boundaries of the Congo Craton and the continental margin. How might these two significant boundaries in the lithosphere interact to influence the CVL?

As a volcanic line without age progression, the CVL challenges many of our current understandings of mantle dynamics and drivers of volcanic activity. Recent studies have yielded insights into the seismicity and crustal and upper mantle structure of the CVL, suggesting that the CVL does not form primarily from a mantle plume or from multiple mantle plumes as suggested for non-age progressive volcanic lines in the south Pacific. Instead, 
the CVL is likely influenced by the interaction between mantle convection and the unique preexisting lithospheric structures in the region. Questions still remain about the relative contributions of different preexisting structure and about the nature of the offshore portions of the CVL. Further study focusing on the oceanic sector and finer scale structures of the continental sector are needed to address key outstanding questions.

\section{AUTHOR CONTRIBUTIONS}

AA performed the analysis, wrote the text, and designed all original figures.

\section{REFERENCES}

Adams, A. N., Wiens, D. A., Nyblade, A. A., Euler, G. G., Shore, P. J., and Tibi, R. (2015). Lithospheric Instability and the Source of the Cameroon Volcanic Line: Evidence from Rayleigh Wave Phase Velocity Tomography. J. Geophys. Res. Solid Earth 120, 1708-1727. doi:10.1002/2014jb011580

Aka, F. T., Nagao, K., Kusakabe, M., and Nfomou, N. (2009). Cosmogenic Helium and Neon in Mantle Xenoliths from the Cameroon Volcanic Line (West Africa): Preliminary Observations. J. Afr. Earth Sci. 55, 175-184. doi:10. 1016/j.jafrearsci.2009.04.002

Albuquerque Seismological Laboratory (ASL)/USGS (1988). Data from Global Seismograph Network - IRIS/USGS. International Federation of Digital Seismograph Networks. doi:10.7914/SN/IU

Ambeh, W. B., Fairhead, J. D., Francis, D. J., Nnange, J. M., and Djallo, S. (1989). Seismicity of the Mount Cameroon Region, West Africa. J. Afr. Earth Sci. 7, 107. doi:10.1016/0899-5362(89)90002-x

Ambeh, W. B., and Fairhead, J. D. (1991). Regular, Deep Seismicity beneath Mt Cameroon Volcano: Lack of Evidence for Tidal Triggering. Geophys. J. Int. 106, 287-291. doi:10.1111/j.1365-246x.1991.tb04618.x

Ambraseys, N. N., and Adams, R. D. (1986). Seismicity of West Africa. Ann. Geophys. Series B Terr. Planet. Phys. 4 (6), 679-702.

Asaah, A. N. E., Yokoyama, T., Aka, F. T., Usui, T., Wirmvem, M. J., Tchamabe, B. C., et al. (2015). A Comparative Review of Petrogenetic Processes beneath the Cameroon Volcanic Line: Geochemical Constraints. Geosci. Front. 6, 557-570. doi:10.1016/j.gsf.2014.04.012

Betchtel, T. D. D., Forsyth, D. W., and Swain, C. (1987). Mechanism of Isostatic Compensation in the Vicinity of the East African Rift, Kenya. Geophys. J. R. Astron. Soc. 90, 445-465. doi:10.1111/j.1365-246x.1987.tb00734.x

Bonatti, E., and Harrison, C. G. A. (1976). Hot Lines in the Earth's Mantle. Nature 263, 402-404. doi:10.1038/263402a0

Bonneville, A., Dosso, L., and Hildenbrand, A. (2006). Temporal Evolution and Geochemical Variability of the South Pacific Superplume Activity. Earth Planet. Sci. Lett. 244 (1-2), 251-269. doi:10.1016/j.epsl.2005.12.037

Bonvalot, S., Balmino, G., Briais, A., Kuhn, M., Peyrefitte, A., Vales, N., et al. (2012). in World Gravity Map. Commission for the Geological Map of the World (Paris: BGI-CGMW-CNES-IRD).

Boukeke, D. B. (1994). Structures crustales d'Afrique Centrale déduites des anomalies gravimétriques et magnétiques: le domaine précambrien de la République Centrafricaine et du Sud Cameroun. Thèse Univ. Paris XI, Orsay, $263 \mathrm{pg}$.

Browne, S. E., and Fairhead, J. D. (1983). Gravity Study of the Central African Rift System: A Model of Continental Disruption: 1. The Ngaoundere and ABU Gabra Rifts. Tectonophysics 94 (1-4), 187-203. doi:10.1016/b978-0-444-421982.50018-3

Burke, K. C., Dessauvagie, T. F. J., and Whiteman, A. J. (1970). "Geological History of the Benue Valley and Adjacent Areas," in African Geology. Editors T. F. J. Dessauvagie and A. J. Whiteman (Nigeria: University of Ibadan), 187-205.

Burke, K., Dessauvagie, T. F. J., and Whiteman, A. J. (1971). Opening of the Gulf of Guinea and Geological History of the Benue Depression and Niger delta. Nat. Phys. Sci. 233 (38), 51-55. doi:10.1038/physci233051a0

\section{FUNDING}

This work is funded by Colgate University.

\section{ACKNOWLEDGMENTS}

The author has benefited from numerous conversations about the CVL and forms of mantle convection, and particularly wishes to thank Douglas Wiens, Andrew Nyblade, Karen Harpp, Samantha Hansen, and Angela Reusch for their insights. The author thanks the reviewers for their comments, which improved the manuscript.

Burke, K. (2001). Origin of the Cameroon Line of Volcano-Capped Swells. J. Geology. 109 (3), 349-362. doi:10.1086/319977

Burke, K., and Torsvik, T. H. (2004). Derivation of Large Igneous Provinces of the Past 200 Million Years from Long-Term Heterogeneities in the Deep Mantle. Earth Planet. Sci. Lett. 227, 531-538. doi:10.1016/j.epsl.2004.09.015

Campbell, I. H. (2007). Testing the Plume Theory. Chem. Geology. 241, 153-176. doi:10.1016/j.chemgeo.2007.01.024

Carter, J. D., Barber, W., and Tait, E. A. (1963). The Geology of Parts of Adamawa, Bauchi and Bornu Provinces in Northeastern Nigeria. Bull. Geol. Surv. Nigeria 30, 109.

Castaing, C., Feybesse, J. L., Thiéblemont, D., Triboulet, C., and Chèvremont, P. (1994). Palaeogeographical Reconstructions of the Pan-African/Brasiliano Orogen: Closure of an Oceanic Domain or Intracontinental Convergence between Major Blocks. Precambrian Res. 69, 327-344. doi:10.1016/03019268(94)90095-7

Chadwick, J., Perfit, M. R., Ridley, I. A., Jonasson, I. R., Kamenov, G. D., Chadwick, W. W., et al. (2005). Magmatic effects of the Cobb hot spot on the Juan de Fuca Ridge. J. Geophys. Res. 110, 1-16. doi:10.1029/2003jb002767

Collignon, F. (1968). Gravimetrie de Reconnaissance. Paris: Cameroun ORSTOM.

Cornen, G., and Maury, R. C. (1980). Petrology of the Volcanic Island of Annobon, Gulf of Guinea. Mar. Geology. 36 (3-4), 253-267. doi:10.1016/0025-3227(80) 90090-0

Davies, J. H., and Bunge, H.-P. (2006). Are Splash Plumes the Origin of Minor Hotspots. Geol 34, 349-352. doi:10.1130/g22193.1

Déruelle, B., Moreau, C., Nkoumbou, C., Kambou, R., Lissom, J., Njonfang, E., et al. (1991). "The Cameroon Line: A Review," in Magmatism in Extensional Tectonic Structural Settings. Editors A. B. Kampunzu and R. T. Lubala (Berlin: Springer), 274-327.

Déruelle, B., Ngounouno, I., and Demaiffe, D. (2007). The 'Cameroon Hot Line' (CHL): A Unique Example of Active Alkaline Intraplate Structure in Both Oceanic and continental Lithospheres. Comptes Rendus Geosci. 339, 589-600. doi:10.1016/j.crte.2007.07.007

De Plaen, R. S. M., Bastow, I. D., Chambers, E. L., Keir, D., Gallacher, R. J., and Keane, J. (2014). The Development of Magmatism along the Cameroon Volcanic Line: Evidence from Seismicity and Seismic Anisotropy. J. Geophys. Res. Solid Earth 119, 4233-4252. doi:10.1002/2013JB010583

Dorbath, C., Dorbath, L., Fairhead, J. D., and Stuart, G. W. (1986). A Teleseismic Delay Time Study across the Central African Shear Zone in the Adamawa Region of Cameroon, West Africa. Geophys. J. Int. 86 (3), 751-766. doi:10.1111/ j.1365-246x.1986.tb00658.x

Duncan, R. A., and Richards, M. A. (1991). Hotspots, Mantle Plumes, Flood Basalts, and True Polar Wander. Rev. Geophys. 29, 31-50. doi:10.1029/90rg02372

Dunlap, H. M. (1983). Strontium Isotope Geochemistry and Potassium-Argon Studies on Volcanic Rocks from the Cameroon Line. West Africa, Ph.D thesis. Edinburgh, U.K: University of Edinburgh.

Dunlop, H. M., and Fitter, J. G. (1979). A K-Ar and Sr-Isotopic Study of the Volcanic Rocks of the Island of Principe, West Africa? Evidence for Mantle Heterogeneity beneath the Gulf of Guinea. Contrib. Mineral. Petrol. 71 (2), 125-131. doi:10.1007/BF00375428

Ebinger, C. J., Bechtel, T. D., Forsyth, D. W., and Bowin, C. O. (1989). Effective Elastic Plate Thickness beneath the East African and Afar Plateaus and 
Dynamic Compensation of the Uplifts. J. Geophys. Res. 94, 2883-2901. doi:10. 1029/jb094ib03p02883

Ebinger, C. J., Keir, D., Bastow, I. D., Whaler, K., Hammond, J. O. S., Ayele, A., et al. (2017). Crustal Structure of Active Deformation Zones in Africa: Implications for Global Crustal Processes. Tectonics 36, 3298-3332. doi:10.1002/ $2017 \mathrm{tc} 004526$

Ebinger, C. J., and Sleep, N. H. (1998). Cenozoic Magmatism throughout East Africa Resulting from Impact of a Single Plume. Nature 395, 788-791. doi:10. $1038 / 27417$

Elsheikh, A. A., Gao, S. S., and Liu, K. H. (2014). Formation of the Cameroon Volcanic Line by Lithospheric Basal Erosion: Insight from Mantle Seismic Anisotropy. J. Afr. Earth Sci. 100, 96-108. doi:10.1016/j.jafrearsci.2014.06.011

Emery, K. O., Uchupi, E., Phillips, J., Brown, C., and Mascle, J. (1975). Continental Margin off West Africa: Angola to Sierra Leone. AAPG Bull. 59, 2209-2265. doi:10.1306/83d92249-16c7-11d7-8645000102c1865d

Emry, E. L., Shen, Y., Nyblade, A. A., Flinders, A., and Bao, X. (2019). Upper Mantle Earth Structure in Africa from Full-Wave Ambient Noise Tomography. Geochem. Geophys. Geosyst. 20, 120-147. doi:10.1029/2018GC007804

Epp, D. (1984). Possible Perturbations to Hotspot Traces and Implications for the Origin and Structure of the Line Islands. J. Geophys. Res. 89 (273-11), 286. doi:10.1029/jb089ib13p11273

Eyike, A., and Ebbing, J. (2015). Lithospheric Structure of the West and Central African Rift System from Regional Three-Dimensional Gravity Modelling. South. Afr. J. Geology. 118, 285-298. doi:10.2113/gssajg.118.3.285

Fairhead, J. D., and Okereke, C. S. (1987). A Regional Gravity Study of the West African Rift System in Nigeria and Cameroon and its Tectonic Interpretation. Tectonophysics 143 (1-3), 141-159. doi:10.1016/0040-1951(87)90084-9

Fairhead, J. D. (1985). Preliminary Study of the Seismicity Associated with the Cameroon Volcanic Province during the Volcanic Eruption of Mt. Cameroon in 1982. J. Afr. Earth Sciencies 3, 197-301. doi:10.1016/0899-5362(85)90003-x

Farnetani, C. G., and Samuel, H. (2005). Beyond the thermal Plume Paradigm. Geophys. Res. Lett. 32, a-n. doi:10.1029/2005GL022360

Fishwick, S. (2010). Surface Wave Tomography: Imaging of the LithosphereAsthenosphere Boundary beneath central and Southern Africa. Lithos 120, 63-73. doi:10.1016/j.lithos.2010.05.011

Fitton, J. G., and Dunlop, H. M. (1985). The Cameroon Line, West Africa, and its Bearing on the Origin of Oceanic and continental Alkali basalt. Earth Planet. Sci. Lett. 72 (1), 23-38. doi:10.1016/0012-821X(85)90114-1

Fitton, J. G., Kilburn, C. R. J., Thirlwall, M. F., and Hughes, D. J. (1983). 1982 Eruption of Mount Cameroon, West Africa. Nature 306, 327-332. doi:10.1038/ $306327 \mathrm{a} 0$

Fitton, J. G. (1980). The Benue Trough and cameroon Line - A Migrating Rift System in West Africa. Earth Planet. Sci. Lett. 51 (1), 132-138. doi:10.1016/ 0012-821x(80)90261-7

Fitton, J. G. (1987). The Cameroon Line, West Africa: a Comparison between Oceanic and continental Alkaline Volcanism. Geol. Soc. Lond. Spec. Publications 30, 273-291. doi:10.1144/gsl.sp.1987.030.01.13

Floberghagen, R., Fehringer, M., Lamarre, D., Muzi, D., Frommknecht, B., Steiger, C., et al. (2011). Mission Design, Operation and Exploitation of the Gravity Field and Steady-State Ocean Circulation Explorer mission. J. Geod 85 (11), 749-758. doi:10.1007/s00190-011-0498-3

French, S. W., and Romanowicz, B. A. (2014). Whole-mantle Radially Anisotropic Shear Velocity Structure from Spectral-Element Waveform Tomography. Geophys. J. Int. 199, 1303-1327. doi:10.1093/gii/ggu334

French, S. W., and Romanowicz, B. (2015). Broad Plumes Rooted at the Base of the Earth's Mantle beneath Major Hotspots. Nature 525, 95-99. doi:10.1038/ nature 14876

Gallacher, R. J., and Bastow, I. D. (2012). The Development of Magmatism along the Cameroon Volcanic Line: Evidence from Teleseismic Receiver Functions. Tectonics 31, a-n. doi:10.1029/2011TC003028

Gilardoni, M., Reguzzoni, M., and Sampietro, D. (2016). GECO: a Global Gravity Model by Locally Combining GOCE Data and EGM2008. Stud. Geophys. Geod 60, 228-247. doi:10.1007/s11200-015-1114-4

Goussi Ngalamo, J. F., Sobh, M., Bisso, D., Abdelsalam, M. G., Atekwana, E., and Ekodeck, G. E. (2018). Lithospheric Structure beneath the Central Africa Orogenic Belt in Cameroon from the Analysis of Satellite Gravity and Passive Seismic Data. Tectonophysics 745, 326-337. doi:10.1016/j.tecto.2018. 08.015
Grant, N. K., Rex, D. C., and Freeth, S. J. (1972). Potassium-argon Ages and Strontium Isotope Ratio Measurements from Volcanic Rocks in Northeastern Nigeria. Contr. Mineral. Petrol. 35 (4), 277-292. doi:10.1007/BF00371310

Gripp, A. E., and Gordon, R. G. (1990). Current Plate Velocities Relative to the Hotspots Incorporating the NUVEL-1 Global Plate Motion Model. Geophys. Res. Lett. 17, 1109-1112. doi:10.1029/GL017i008p01109

Grunau, H. R., Lehner, P., Cleintuar, M. R., Allenbach, P., and Bakker, G. (1975). "New Radiometric Ages and Seismic Data from Fuerteventura (Canary Islands)," in Maio (Caper Verde Islands), and São Tomé (Gulf of Guinea) (New York: North-Holland), 90-118.

Guidarelli, M., and Aoudia, A. (2016). Ambient Noise Tomography of the Cameroon Volcanic Line and Northern Congo Craton: New Constraints on the Structure of the Lithosphere. Geophys. J. Int. 204, 1756-1765. doi:10.1093/ gji/ggv561

Hansen, S. E., Nyblade, A. A., and Benoit, M. H. (2012). Mantle Structure beneath Africa and Arabia from Adaptively Parameterized P-Wave Tomography: Implications for the Origin of Cenozoic Afro-Arabian Tectonism. Earth Planet. Sci. Lett. 319-320, 23-34. doi:10.1016/j.epsl.2011.12.023

Hedberg, J. D. (1969). A Geological Analysis of the Cameroon Trend. Ph.D. thesis. Princeton, New Jersey: Princeton University.

Jaupart, C., Molnar, P., and Cottrell, E. (2007). Instability of a Chemically Dense Layer Heated from below and Overlain by a Deep Less Viscous Fluid. J. Fluid Mech. 572, 433-469. doi:10.1017/s0022112006003521

Kagou Dongmo, A., Nkouathio, D., Pouclet, A., Bardintzeff, J.-M., Wandji, P., Nono, A., et al. (2010). The Discovery of Late Quaternary basalt on Mount Bambouto: Implications for Recent Widespread Volcanic Activity in the Southern Cameroon Line. J. Afr. Earth Sci. 57, 96-108. doi:10.1016/j. jafrearsci.2009.07.015

Kamgang, P., Njonfang, E., Nono, A., Dedzo, M. G., and Tchoua, F. M. (2010). Petrogenesis of a Silicic Magma System: Geochemical Evidence from Bamenda Mountains, NW Cameroon, Cameroon Volcanic Line. J. Afr. Earth Sci. 58, 285-304. doi:10.1016/j.jafrearsci.2010.03.008

Kemgang Ghomsi, F., Severin, N., Mandal, A., Nyam, F. E., Tenzer, R., and Tokam Kamga, A. (2020). Cameroon's Crustal Configuration from Global Gravity and Topographic Models and Seismic Data. J. Afr. Earth Sci., 161. doi:10.1016/j. jafrearsci.2019.103657

King, S. D., and Anderson, D. L. (1995). An Alternative Mechanism of Flood basalt Formation. Earth Planet. Sci. Lett. 136, 269-279. doi:10.1016/0012-821x(95) 00205-q

King, S. D., and Anderson, D. L. (1998). Edge-driven Convection. Earth Planet. Sci. Lett. 160, 289-296. doi:10.1016/s0012-821x(98)00089-2

King, S. D., and Ritsema, J. (2000). African Hot Spot Volcanism: Small-Scale Convection in the Upper Mantle beneath Cratons. Science 290 (5494), 1137-1140. doi:10.1126/science.290.5494.1137

Koch, F. W., Wiens, D. A., Nyblade, A. A., Shore, P. J., Tibi, R., Ateba, B., et al. (2012). Upper-mantle Anisotropy beneath the Cameroon Volcanic Line and Congo Craton from Shear Wave Splitting Measurements. Geophys. J. Int. 190, 75-86. doi:10.1111/j.1365-246X.2012.05497.x

Koppers, A. A. P., Staudigel, H., Pringle, M. S., and Wijbrans, J. R. (2003). Shortlived and Discontinuous Intraplate Volcanism in the South Pacific: Hot Spots or Extensional Volcanism. Geochem. Geophys. Geosyst. 4 (10), 1089. doi:10.1029/ 2003GC000533

Lee, D.-C., Halliday, A. N., Fitton, J. G., and Poli, G. (1994). Isotopic Variations with Distace and Time in the Volcanic Islands of the Cameroon Line: Evidence for a Mantle Plume Origin. Earth Planet. Sci. Lett. 123 (1-3), 119-138. doi:10. 1016/0012-821X(94)90262-3

Lehner, P., and de Ruiter, P. A. C. (1977). Structural History of Atlantic Margin of Africa. AAPG Bull. 61, 961-981. doi:10.1306/c1ea43b0-16c9-11d7$8645000102 \mathrm{c} 1865 \mathrm{~d}$

Maluski, H., Coulon, C., Popoff, M., and Baudin, P. (1995). 40Ar/39Ar Chronology, Petrology and Geodynamic Setting of Mesozoic to Early Cenozoic Magmatism from the Benue Trough, Nigeria. J. Geol. Soc. 152, 311-326. doi:10.1144/gsggs.152.2.0311

Marzoli, A., Renne, P. R., Piccirillo, E. M., Francesca, C., Bellieni, G., Melfi, A. J., et al. (1999). Silicic Magmas from the continental Cameroon Volcanic Line (Oku, Bambouto and Ngaoundere): 40Ar-39Ar Dates, Petrology, Sr-Nd-O Isotopes and Their Petrogenetic Significance. Contrib. Mineral. Petrol. 135 (2-3), 133-150. doi:10.1007/s004100050502 
Marzoli, A., Piccirillo, E. M., Renne, P. R., Bellieni, G., Iacumin, M., Nyobe, J. B., et al. (2000). The Cameroon Volcanic Line Revisited: Petrogenesis of continental Basaltic Magmas from Lithospheric and Asthenospheric Mantle Sources. J. Pet. 41 (1), 87-109. doi:10.1093/petrology/41.1.87

Meyers, J. B., Rosendahl, B. R., Harrison, C. G. A., and Ding, Z.-D. (1998). Deepimaging Seismic and Gravity Results from the Offshore Cameroon Volcanic Line, and Speculation of African Hotlines. Tectonophysics 284, 31-63. doi:10. 1016/s0040-1951(97)00173-x

Meyers, J. B., and Rosendahl, B. R. (1991). Seismic Reflection Character of the Cameroon Volcanic Line: Evidence for Uplifted Oceanic Crust. Geol 19, 1072-1076. doi:10.1130/0091-7613(1991)019<1072:srcotc >2.3.co;2

Milelli, L., Fourel, L., and Jaupart, C. (2012). A Lithospheric Instability Origin for the Cameroon Volcanic Line. Earth Planet. Sci. Lett. 335-336, 80-87. doi:10. 1016/j.epsl.2012.04.028

Molnar, P., and Stock, J. (1987). Relative Motions of Hotspots in the Pacific, Atlantic and Indian Oceans since Late Cretaceous Time. Nature 327, 587-591. doi: $10.1038 / 327587 \mathrm{a} 0$

Morgan, W. J. (1971). Convection Plumes in the Lower Mantle. Nature 230, 42-43. doi:10.1038/230042a0

Morgan, W. J. (1972). Plate Motions and Deep Mantle Convection. Geol. Soc. America Mem. Stud. Earth Space Sci. 132, 7-22. doi:10.1130/MEM132-p7

Morgan, W. J. (1983). Hotspot Tracks and the Early Rifting of the Atlantic. Tectonophysics 94, 123-139. doi:10.1016/0040-1951(83)90013-6

Mulibo, G. D., and Nyblade, A. A. (2013). The P and S Wave Velocity Structure of the Mantle beneath Eastern Africa and the African Superplume Anomaly. Geochem. Geophys. Geosyst. 14, 2696-2715. doi:10.1002/ggge.20150

Ngako, V., Njonfang, E., Aka, F. T., Affaton, P., and Nnange, J. M. (2006). The North-South Paleozoic to Quaternary Trend of Alkaline Magmatism from Niger-Nigeria to Cameroon: Complex Interaction between Hotspots and Precambrian Faults. J. Afr. Earth Sci. 45 (3), 241-256. doi:10.1016/j. jafrearsci.2006.03.003

Ngounouno, I., Deruelle, B., Demaiffe, D., and Montigny, R. (1997). New Data on the Cenozoic Volcanism of the Garoua valley (Upper Benue Trough, Northern Cameroon). C. r. Acad. Sci. Ser. Earth Planet. Sci. 325 (2), 87-94.

Ngounouno, I., Moreau, C., Deruelle, B., Demaiffe, D., and Montigny, R. (2001). Petrologie du complexe alcalin sous-sature de Kokoumi (Cameroun). Bull. Soc. Geol. Fr. 172 (6), 675-686. doi:10.2113/172.6.675

Ngounouno, I., Déruelle, B., Demaiffe, D., and Montigny, R. (2003). Les monchiquites de Tchircotché, vallée de la haute Bénoué (Nord du Cameroun). Comptes Rendus Geosci. 335 (3), 289-296. doi:10.1016/S16310713(03)00047-6

Ngounouno, I., D ruelle, B., Montigny, R., and Demaiffe, D. (2005). Petrology and Geochemistry of Monchiquites from Tchircotch (Garoua Rift, north Cameroon, Central Africa). Mineralogy Pet. 83 (3-4), 167-190. doi:10.1007/ s00710-004-0068-y

Ngounouno, I., Déruelle, B., Montigny, R., and Demaiffe, D. (2006). Les camptonites du mont Cameroun, Cameroun, Afrique. Comptes Rendus Geosci. 338 (8), 537-544. doi:10.1016/j.crte.2006.03.015

Njilah, I. K., Ajonina, H. N., Kamgang, K. V., and Tchindjang, M. (2004). K-Ar Ages, Mineralogy, Major and Trace Element Geochemistry of the TertiaryQuaternary Lavas from the Ndu Volcanic Ridge N.W. Cameroon. Afr. J. Sci. Technol. 5 (1), 47-56. doi:10.4314/ajst.v5i1.15318

Njome, M. S., and de Wit, M. J. (2014). The Cameroon Line: Analysis of an Intraplate Magmatic Province Transecting Both Oceanic and continental Lithospheres: Constraints, Controversies and Models. Earth-Science Rev. 139, 168-194. doi:10.1016/j.earscirev.2014.09.003

Nzenti, J. P., Barbey, P., Macaudiere, J., and Soba, D. (1988). Origin and Evolution of the Late Precambrian High-Grade Yaounde Gneisses (Cameroon). Precambrian Res. 38 (2), 91-109. doi:10.1016/0301-9268(88)90086-1

Nzenti, J. P., Kapajika, B., Wörner, G., and Lubala, T. R. (2006). Synkinematic Emplacement of Granitoids in a Pan-African Shear Zone in Central Cameroon. J. Afr. Earth Sci. 45 (1), 74-86. doi:10.1016/j.jafrearsci.2006.01.005

O'Connor, J. M., and Le Roex, A. P. (1992). South Atlantic Hot Spot-Plume Systems: 1. Distribution of Volcanism in Time and Space. Earth Planet. Sci. Lett. 113, 343-364. doi:10.1016/0012-821x(92)90138-1

Ojo, A. O., Ni, S., Chen, H., and Xie, J. (2018). Crust-mantle Coupling Mechanism in Cameroon, West Africa, Revealed by 3D S-Wave Velocity and Azimuthal
Anisotropy. Phys. Earth Planet. Interiors 274, 195-213. doi:10.1016/j.pepi.2017. 12.006

Ojo, A. O., Ni, S., Xie, J., and Zhao, L. (2019). Further Constraints on the Shear Wave Velocity Structure of Cameroon from Joint Inversion of Receiver Function, Rayleigh Wave Dispersion and Ellipticity Measurements. Geophys. J. Int. 217, 589-619. doi:10.1093/gji/ggz008

Okereke, C. S. (1988). Contrasting Modes of Rifting: The Benue Trough and Cameroon Volcanic Line, West Africa. Tectonics 7, 775-784. doi:10.1029/ tc007i004p00775

Olade, M. A. (1978). Early Cretaceous basalt Volcanism and Initial continental Rifting in Benue Trough, Nigeria. Nature 273, 458-459. doi:10.1038/273458a0

Pautot, G., Renard, V., Daniel, J., and Dupont, J. (1973). Morphology, Limits, Origin, and Age of Salt Layer along South Atlantic Margin. Am. Assoc. Pet. Geologists Bull. 57, 1658-1671. doi:10.1306/83d91024-16c7-11d7$8645000102 \mathrm{c} 1865 \mathrm{~d}$

Penn State University (2004). Data from: AfricaArray. International Federation of Digital Seismograph Networks. doi:10.7914/SN/AF

Poudjom Djomani, Y. H., Nnange, J. M., Diament, M., Ebinger, C. J., and Fairhead, J. D. (1995). Effective Elastic Thickness and Crustal Thickness Variations in West central Africa Inferred from Gravity Data. J. Geophys. Res. 100 (B11), 22047-22070. doi:10.1029/95JB01149

Poudjom Djomani, Y. H., Diament, M., and Wilson, M. (1997). Lithospheric Structure across the Adamawa Plateau (Cameroon) from Gravity Studies. Tectonophysics 273 (3-4), 317-327. doi:10.1016/s0040-1951(96)00280-6

Reigber, C., Lühr, H., and Schwintzer, P. (2002). CHAMP mission Status. Adv. Space Res. 30 (2), 129-134. doi:10.1016/s0273-1177(02)00276-4

Reusch, A. M., Nyblade, A. A., Ateba, B., Wiens, D. A., Shore, P. J., Tabod, C. T., et al. (2010). Upper Mantle Structure beneath Cameroon from Body Wave Tomography and the Origin of the Cameroon Volcanic Line. Geochem. Geophys. Geosyst. 11 (10), a-n. doi:10.1029/2010GC003200

Reusch, A. M., Nyblade, A. A., Tibi, R., Wiens, D. A., Shore, P. J., Bekoa, A., et al. (2011). Mantle Transition Zone Thickness beneath Cameroon: Evidence for an Upper Mantle Origin for the Cameroon Volcanic Line. Geophys. J. Int. 187, 1146-1150. doi:10.1111/j.1365-246X.2011.05239.x

Richter, F. M. (1973). Convection and the Large-Scale Circulation of the Mantle. J. Geophys. Res. 78, 8735-8745. doi:10.1029/jb078i035p08735

Richter, F. M., and Parsons, B. (1975). On the Interaction of Two Scales of Convection in the Mantle. J. Geophys. Res. 80, 2529-2541. doi:10.1029/ jb080i017p02529

Saria, E., Calais, E., Altamimi, Z., Willis, P., and Farah, H. (2013). A New Velocity Field for Africa from Combined GPS and DORIS Space Geodetic Solutions: Contribution to the Definition of the African Reference Frame (AFREF). JGR Solid Earth 118, 1677-1697. doi:10.1002/jgrb.50137

Sebai, A., Stutzmann, E., Montagner, J.-P., Sicilia, D., and Beucler, E. (2006). Anisotropic Structure of the African Upper Mantle from Rayleigh and Love Wave Tomography. Phys. Earth Planet. Interiors 155, 48-62. doi:10.1016/j.pepi. 2005.09.009

Steinberger, B. (2000). Plumes in a Convecting Mantle: Models and Observations for Individual Hotspots. J. Geophys. Res. 105 (B5), 11127-11152. doi:10.1029/ 1999JB900398

Steinberger, B., Sutherland, R., and O'Connell, R. J. (2004). Prediction of EmperorHawaii Seamount Locations from a Revised Model of Global Plate Motion and Mantle Flow. Nature 430, 167-173. doi:10.1038/nature02660

Stuart, G. W., Fairhead, J. D., Dorbath, L., and Dorbath, C. (1985). A Seismic Refraction Study of the Crustal Structure Associated with the Adamawa Plateau and Garoua Rift, Cameroon, West Africa. Geophys. J. Int. 81, 1-12. doi:10.1111/ j.1365-246x.1985.tb01346.x

Tabod, C. T., Fairhead, J. D., Stuart, G. W., Ateba, B., and Ntepe, N. (1992). Seismicity of the Cameroon Volcanic Line, 1982-1990. Tectonophysics 212 (3-4), 303-320. doi:10.1016/0040-1951(92)90297-J

Tadjou, J. M., Nouayou, R., Kamguia, J., Kande, H. L., and Manguelle-Dicoum, E. (2009). Gravity Analysis of the Boundary between the Congo Craton and the Pan-African Belt of Cameroon. Austrian J. Earth Sci. 102 (1), 71-79.

Tapley, B. D., Bettadpur, S., Watkins, M., and Reigber, C. (2004). The Gravity Recovery and Climate experiment: mission Overview and Early Results. Geophys. Res. Lett. 31, L09607. doi:10.1029/2004GL01977910.1029/ $2004 \mathrm{gl019920}$ 
Thompson, D. A., Bastow, I. D., Helffrich, G., Kendall, J.-M., Wookey, J., Snyder, D. B., et al. (2010). Precambrian Crustal Evolution: Seismic Constraints from the Canadian Shield. Earth Planet. Sci. Lett. 297, 655-666. doi:10.1016/j.epsl.2010. 07.021

Tokam, A.-P. K., Tabod, C. T., Nyblade, A. A., Julià, J., Wiens, D. A., and Pasyanos, M. E. (2010). Structure of the Crust beneath Cameroon, West Africa, from the Joint Inversion of Rayleigh Wave Group Velocities and Receiver Functions. Geophys. J. Int. 183, 1061-1076. doi:10.1111/j.1365-246X.2010.04776.x

Toteu, S. F., Penaye, J., and Djomani, Y. P. (2004). Geodynamic Evolution of the Pan-African belt in central Africa with Special Reference to Cameroon. Can. J. Earth Sci. 41 (1), 73-85. doi:10.1139/e03-079

Uzuakpunwa, A. B. (1974). The Abakaliki Pyroclastics - Eastern Nigeria: New Age and Tectonic Implications. Geol. Mag. 111, 65-69. doi:10.1017/ s0016756800000467

Van Houten, F. B. (1983). Sirte Basin, north-central Libya: Cretaceous Rifting above a Fixed Mantle Hotspot. Geol 11, 115-118. doi:10.1130/0091-7613(1983) $11<115$ :sbnlcr $>2.0 . \mathrm{co} ; 2$

Vicat, J., Leger, J., Nsifa, E., Piguet, P., Nzenti, J., Tchameni, R., et al. (1996). "Distinction within the Congo Craton in South-West Cameroon of Two Doleritic Episodes Initiating the Eburnean (Paleoproterozoic) and PanAfrican (Neoproterozoic) Orogenic Cycles,". Comptes Rendus de l'Academie de Sciences - Serie IIa: Sciences de la Terre et des Planetes, 323, 575-582.

Watts, A. B., ten Brink, U. S., Buhl, P., and Brocher, T. M. (1985). A Multichannel Seismic Study of Lithospheric Flexure across the Hawaiian-Emperor Seamount Chain. Nature 315, 105-111. doi:10.1038/315105a0
White, W. M. (2010). Oceanic Island Basalts and Mantle Plumes: The Geochemical Perspective. Annu. Rev. Earth Planet. Sci. 38, 133-160. doi:10.1146/annurevearth-040809-152450

Wiens, D., and Nyblade, A. (2005). Data from: Broadband Seismic Investigation of the Cameroon Volcanic Line. International Federation of Digital Seismograph Networks. doi:10.7914/SN/XB_2005

Wilson, J. T. (1963). A Possible Origin of the Hawaiian Islands. Can. J. Phys. 41, 863-870. doi:10.1139/p63-094

Conflict of Interest: The author declares that the research was conducted in the absence of any commercial or financial relationships that could be construed as a potential conflict of interest.

Publisher's Note: All claims expressed in this article are solely those of the authors and do not necessarily represent those of their affiliated organizations, or those of the publisher, the editors and the reviewers. Any product that may be evaluated in this article, or claim that may be made by its manufacturer, is not guaranteed or endorsed by the publisher.

Copyright (C) 2022 Adams. This is an open-access article distributed under the terms of the Creative Commons Attribution License (CC BY). The use, distribution or reproduction in other forums is permitted, provided the original author(s) and the copyright owner(s) are credited and that the original publication in this journal is cited, in accordance with accepted academic practice. No use, distribution or reproduction is permitted which does not comply with these terms. 